\title{
Targeted GAS6 Delivery to the CNS Protects Axons from Damage during Experimental Autoimmune Encephalomyelitis
}

\author{
Ross C. Gruber, ${ }^{1}$ Alex K. Ray, ${ }^{1}$ Christopher T. Johndrow, ${ }^{2}$ Hillary Guzik, ${ }^{3}$ Dominika Burek, ${ }^{1}$ Pablo García de Frutos, ${ }^{4}$ \\ and Bridget Shafit-Zagardo ${ }^{1}$ \\ ${ }^{1}$ Department of Pathology, ${ }^{2}$ Department of Microbiology and Immunology, and ${ }^{3}$ Analytical Imaging Facility, Department of Anatomy and Structural \\ Biology, Albert Einstein College of Medicine, Yeshiva University, Jack and Pearl Resnick Campus, Bronx, New York 10461, and ${ }^{4}$ Department of Cell Death \\ and Proliferation, Institute of Biomedical Research of Barcelona, Barcelona 08036, Spain
}

Growth arrest-specific protein 6 (GAS6) is a soluble agonist of the TYR03, AXL, MERTK (TAM) family of receptor tyrosine kinases identified to have anti-inflammatory, neuroprotective, and promyelinating properties. During experimental autoimmune encephalomyelitis (EAE), wild-type (WT) mice demonstrate a significant induction of Gas6, Axl, and Mertk but not Pros 1 or Tyro3 mRNA. We tested the hypothesis that intracerebroventricular delivery of GAS6 directly into the CNS of WT mice during myelin oligodendrocyte glycoprotein (MOG)-induced EAE would improve the clinical course of disease relative to artificial CSF (ACSF)-treated mice. GAS6 did not delay disease onset, but significantly reduced the clinical scores during peak and chronic EAE. Mice receiving GAS6 for $28 \mathrm{~d}$ had preserved $\mathrm{SMI}_{3} 1^{+}$neurofilament immunoreactivity, significantly fewer SMI $32^{+}$axonal swellings and spheroids and less demyelination relative to ACSF-treated mice. Alternate-day subcutaneous IFN $\beta$ injection did not enhance GAS6 treatment effectiveness. Gas ${ }^{-1-}$ mice sensitized with $\mathrm{MOG}_{35-55}$ peptide exhibit higher clinical scores during late peak to early chronic disease, with significantly increased SMI32 ${ }^{+}$axonal swellings and Iba ${ }^{+}$microglia/macrophages, enhanced expression of several proinflammatory mRNA molecules, and decreased expression of early oligodendrocyte maturation markers relative to WT mouse spinal cords with scores for 8 consecutive days. During acute EAE, flow cytometry showed significantly more macrophages but not T-cell infiltrates in $\mathrm{Gas}^{-1-}$ spinal cords than WT spinal cords. Our data are consistent with GAS6 being protective during EAE by dampening the inflammatory response, thereby preserving axonal integrity and myelination.

Key words: demyelination; EAE; GAS6; inflammation; neuroprotection; TAM receptor

\section{Introduction}

Growth arrest-specific protein 6 (GAS6) is a major vitamin K-dependent, $\gamma$-carboxylated, secreted growth factor that functions in cell survival, adhesion, chemotaxis, mitogenesis, and cell growth. GAS6 is the sole ligand for AXL, one of three members of the TYRO3, AXL and MERTK (TAM) family of receptor tyrosine kinases that are activated by GAS6 (Stitt et al., 1995; Varnum et

\footnotetext{
Received June 12, 2014; revised 0ct. 8, 2014; accepted 0ct. 20, 2014

Author contributions: R.C.G. and B.S.-Z. designed research; R.C.G., A.K.R., C.T.J., D.B., and B.S.-Z. performed research; P.G.d.F. contributed unpublished reagents/analytic tools; R.C.G., A.K.R., C.T.J., H.M.G., D.B., and B.S.-Z. analyzed data; R.C.G. and B.S.-Z. wrote the paper.

This work was supported by the National Multiple Sclerosis Society (Grant RG 4046-A6) and the National Institutes of Health (Grant R21 NS079144-01, Neuropathology Training Grant T32 NS007098, and Cellular and Molecular Biology and Genetics Training Grant T32 GM007491). We thank Brian Varnum (Amgen) for generously providing the recombinant human Gas6 used in this study, Kathleen 0'Guin for genotyping and mouse husbandry, Lauren Bayer for performing qRT-PCR, Rebecca Bauer and Tanvi Goyal for performing SMI32 counts and immunostaining, Daria LaRocca for editing the manuscript, and John Coraje for maintaining the mouse colony.

The authors declare no competing financial interests.

Correspondence should be addressed to Dr. Bridget Shafit-Zagardo, Department of Pathology, Albert Einstein College of Medicine, Yeshiva University, Jack and Pearl Resnick Campus, Forchheimer Building, Room 524, 1300 Morris Park Ave., Bronx, NY 10461. E-mail: Bridget.Shafit-Zagardo@einstein.yu.edu.

DOI:10.1523/JNEUROSCI.2449-14.2014

Copyright $\odot 2014$ the authors $\quad 0270-6474 / 14 / 3416320-16 \$ 15.00 / 0$
}

al., 1995; Nagata et al., 1996). The relative affinity of Gas6 for its receptors is AXL > TYRO3 > MERTK (Nagata et al., 1996; Sasaki et al., 2006). Unlike AXL, TYRO3 and MERTK are also activated by PROS1, another vitamin K-dependent protein that shares $46 \%$ homology with GAS6. PROS1 has an important role in blood coagulation, a role that does not involve TAM receptors or GAS6. Deletion of Pros1 results in embryonic lethality, whereas Gas6 ${ }^{-1-}$ mice are viable (Prasad et al., 2006; Rothlin and Lemke, 2010).

GAS6 is expressed at high levels in the brain during early development and continues to be expressed throughout adulthood (Prieto et al., 1999). TAM receptors are expressed in astrocytes, neurons, oligodendrocytes, and microglia/macrophages. The extracellular domain exhibits amino acid similarity to neural cell adhesion molecules (Prieto et al., 2000).

A study of $\mathrm{Gas6}^{-1-}$ mice during cuprizone-induced demyelination and recovery determined that, relative to C57BL/6J wildtype (WT) mice, Gas6 ${ }^{-1-}$ mice had increased oligodendrocyte loss, delayed remyelination, and prolonged microglial activation 3 weeks after the removal of cuprizone from the diet (Binder et al., 2008). This study is consistent with our findings that, relative to WT mice receiving saline, administration of GAS6 into the 
corpus callosum after cuprizone intoxication enhanced remyelination and recovery (Tsiperson et al., 2010).

In brain homogenates prepared from established multiple sclerosis (MS) lesions, levels of cleaved soluble AXL, membranebound MERTK, and soluble MERTK were all significantly elevated (Weinger et al., 2009). Unlike normal brain tissue, in which GAS6 was positively correlated with soluble AXL and MERTK, there was a negative correlation between GAS6 and soluble AXL and MERTK in established MS lesions. Soluble AXL and MERTK can act as decoy receptors to block GAS6 binding to membranebound receptors (Sather et al., 2007; Weinger et al., 2009). $A x l^{-1-}$ mice are more severely affected during both cuprizone intoxication and recovery and during acute myelin oligodendrocyte glycoprotein (MOG)-induced experimental autoimmune encephalomyelitis (EAE) (Hoehn et al., 2008; Weinger et al., 2011). These data suggest that, in MS lesions and mouse models, dysregulation of protective GAS6 receptor signaling may prolong lesion activity and strongly support a role for GAS6/TAM signaling in the mature nervous system.

In this study, we sought to characterize the role of GAS6 in the preservation of CNS function and recovery after $\mathrm{MOG}_{35-55^{-}}$ induced EAE, a model of autoimmunity that shares several clinical and pathologic features with MS. Induction of EAE disrupts the blood-brain barrier resulting in infiltration of $\mathrm{T}$ cells and monocytes, increased inflammation, expression of proinflammatory molecules, demyelination, and axonal damage. We hypothesized that GAS6 administration during EAE would decrease disease severity, enhance recovery, and reduce long-term axonal damage and, conversely, that loss of GAS6 signaling would increase disease severity.

\section{Materials and Methods}

\section{Mice}

C57BL/6J WT were obtained from The Jackson Laboratory and bred in-house. Gas6 $6^{-1-}$ mice were obtained from Dr. Pablo García de Frutos (Institute of Biomedical Research of Barcelona). All mice were extensively backcrossed on WT C57BL/6J mice by the Shafit-Zagardo laboratory and WT C57BL/6J mice were used as controls. All experiments were performed with 8- to 12-week-old male and female mice. All animal procedures were approved by the Institute of Animal Care and Use Committee at the Albert Einstein College of Medicine in complete compliance with the National Institutes of Health's Guide for Care and Use of Laboratory Animals.

$M O G$-induced EAE: active induction of EAE

$\mathrm{C} 57 \mathrm{BL} / 6 \mathrm{~J}$ and $\mathrm{Gas}^{-1-}$ mice were immunized with $\mathrm{MOG}_{35-55}$ peptide. $\mathrm{MOG}_{35-55}(3 \mathrm{mg} / \mathrm{ml}$; Peptides International) was emulsified in an equal volume of complete Freund's adjuvant (CFA). CFA was composed of Mycobacterium tuberculosis (10 mg/ml; Difco Laboratories) in incomplete Freund's adjuvant (Difco Laboratories). Mice were anesthetized with isoflurane and $100 \mu \mathrm{l}$ of emulsion was injected subcutaneously on each flank (200 $\mu \mathrm{l}$ total/mouse) on day 0 . In addition, $200 \mu \mathrm{l}$ of pertussis toxin (Ptx, $2.5 \mu \mathrm{g} / \mathrm{ml}$; List Biological Laboratories) was injected intraperitoneally on days 0 and 2. Mice were monitored and graded daily for clinical symptoms of disease as follows: $0=$ no disease; $1=\operatorname{limp}$ tail; $2=$ limp tail and hindlimb weakness; $3=$ hindlimb paralysis; $4=$ hindlimb and front limb paralysis; and $5=$ moribund. Mice that did not present with clinical scores were not included in analysis ( $\sim 2 \%$ of total).

Cannulation and micro-osmotic pump implants

Cannulation. Alzet cannulae (Brain Infusion Kit 3) were prepared the night before surgery by sterilely attaching an $\sim 1.5 \mathrm{~cm}$ length of tubing, filling the tube with sterile ACSF, and then sealing the end of the tubing. Mice were anesthetized for the length of the procedure using continuous administration of isoflurane. The scalp of each mouse was shaved and ocular lubricant placed in the eyes. The animal was then secured to a
Stoelting stereotaxic frame within a BSL-2 hood. The shaved scalp was sterilized using Betadine (Purdue Products) followed by isopropanol wipes. A small incision was made using a sterile \#20 scalpel blade; the revealed area of the skull was cleaned using a sterile cotton-tipped applicator. The stereotaxic frame was used to place each cannula at the coordinates $0.4 \mathrm{~mm}$ posterior to bregma, $1 \mathrm{~mm}$ lateral right. Once these coordinates were identified, a small hole was drilled in the skull using a sterilized Dremel 108 engraving cutter (Robert Bosch) and the tubing attached to the cannula was threaded under the skin on the left side of the mouse. The cannula was then positioned $2.5 \mathrm{~mm}$ below the surface of the skull and glued into place using Loctite Prism 454 adhesive followed by a layer of fast curing orthodontic resin (Ortho-Jet; Lang Dental). After surgery, mice were immediately placed on a warm pad until fully recovered from anesthesia and then allowed to heal for 3 weeks before sensitization with MOG.

Pump insertion. Micro-osmotic pumps (Alzet model 1104, $0.11 \mu \mathrm{l} / \mathrm{h}$, $28 \mathrm{~d}$ ) were attached $6 \mathrm{~d}$ after the second Ptx injection. Two days before the surgery, pumps were sterilely loaded with active (Tsou et al., 2014), full-length human $\gamma$-carboxylated GAS6 ( $4 \mu \mathrm{g} / \mathrm{ml}$; Amgen) diluted in ACSF or ACSF alone. In a previous study using GAS6 osmotic pumps for cuprizone recovery, we determined that $400 \mathrm{ng} / \mathrm{ml}$ to $40 \mu \mathrm{g} / \mathrm{ml} \mathrm{GAS6}$ was effective, but $4 \mu \mathrm{g} / \mathrm{ml}$ was the optimal dose (Tsiperson et al., 2010). After loading, pumps were placed in sterile $\mathrm{PBS}$ at $37^{\circ} \mathrm{C}$ to equilibrate and begin pumping. Again, all mice were anesthetized using isoflurane for the length of the procedure and ocular lubricant was used to prevent blindness in the animals. A small area on the back of the mice corresponding to the area where the cannula tubing was placed under the skin was shaved and sterilized as above. A $0.5 \mathrm{~cm}$ incision was made using a \#10 scalpel blade and space for the pump under the skin was made using a sterilized hemostat. The pump was then inserted under the skin; the sealed end of the cannula tubing was removed and the tubing was attached to the pump. The incision was closed using Vet-bond tissue adhesive (3M). The mice were placed on a warm pad, provided with gel food, and allowed to recover from anesthesia. After surgery, the mice were monitored daily. As a result of the length of the tubing from the cannula to the pump, mice began to receive the contents of each pump 2-3 d after attachment.

\section{IFN $\beta$ treatment}

Mice were injected subcutaneously with $3 \times 10^{4}$ units of IFN $\beta$ /Betaseron purchased from Bayer every other day, beginning $7 \mathrm{~d}$ after the second Ptx injection until the conclusion of the experiment.

\section{Spinal cord dissection and tissue preparation}

Mice were anesthetized with isoflurane U.S.P. (ISOTHESIA, Butler Schein) and killed by total body perfusion with $4 \%$ paraformaldehyde (Fisher Scientific) or $1 \times$ PBS, pH 7.3. Spinal cords were removed and dissected into cervical, thoracic, and lumbar regions. Sections were placed in fixative for immunohistochemistry or RNAlater (Life Technologies) for RNA isolation.

\section{Antibodies (Abs), immunohistochemistry, immunofluorescent staining, and stains}

Myelin basic protein (MBP) monoclonal antibody (mAb) SMI99 (1: $2000)$ and neurofilament mAb SMI32 (1:20 000) and mAb SMI31 (1: $10000)$ were purchased from Covance. Ibal polyclonal Ab (1:400) was purchased from Wako Chemicals. CD3 was purchased from Dako. Paraformaldehyde-fixed tissues were stored overnight at $4^{\circ} \mathrm{C}$, transferred to $25 \%$ sucrose, and paraffin embedded. Frozen sections were prepared from the paraformaldehyde-fixed sections. Paraffin-embedded sections $(5 \mu \mathrm{M})$ were immersed in xylene and rehydrated through descending alcohols and brought to $1 \times$ Tris buffered saline, $\mathrm{pH} 7.4$ (1× TBS). Antigen retrieval was achieved by microwaving the slides in boiling distilled water for $7 \mathrm{~min}$ on high power and $7 \mathrm{~min}$ on power 7 . Sections were incubated for 15 min with $1 \times$ TBS containing $0.25 \%$ Triton X-100. Exogenous peroxidase was quenched using $3 \%$ hydrogen peroxide in $1 \times$ TBS for $15 \mathrm{~min}$ at room temperature. Sections were blocked with a $1 \mathrm{~h}$ incubation in 5\% goat serum and 5\% nonfat dry milk in $1 \times$ TBS and incubated with Abs diluted in 5\% nonfat dry milk in $1 \times$ TBS overnight at $4^{\circ} \mathrm{C}$. Sections were washed 3 times in $1 \times$ TBS and incubated with secondary $\mathrm{Ab}$ followed by incubation with the appropriate Vecta staining kit 
(Vector Laboratories) and visualized by diaminobenzidine (DAB; Sigma). Sections were visualized on a Leica Leitz DRMB microscope with an Olympus DP12 camera. For immunofluorescent staining, all secondary antibodies were Alexa Fluor-conjugated isotype specific purchased from Fisher Scientific. Fluorescent images were captured using an Olympus IX81 microscope with a Cooke Sensicam QE.

\section{Quantification of $\mathrm{Iba1}^{+}{ }^{+}$microglia/macrophage inflammatory score}

Before quantification, slides were blinded and at least three sections of lumbar spinal cord for each animal were assessed by two individuals; the number of animals used for each experiment is indicated in the figure legends. Ibal ${ }^{+}$cells in cross-sectional spinal cord were scored on a 1-4 inflammatory scale where $1=$ mild inflammation at lesions, $2=$ moderate inflammation at lesions, $3=$ severe inflammation at lesions, and $4=$ very severe inflammation involving $50 \%$ or more of the spinal cord (Tsiperson et al., 2013). Mann-Whitney $U$ test was used to evaluate statistical significance.

\section{Scoring of demyelination after $\mathrm{MBP}^{+}{ }^{\text {immunohistochemistry }}$ (DAB visualization)}

Before quantification, slide identity was masked to the reviewer and at least three sections of lumbar spinal cord/specimen were assessed by two individuals; the number of animals used for each experiment is indicated in the figure legends. A score of 0 is the equivalent of MBP immunoreactivity observed in naive ventral spinal cord; a score of 0 was not observed in any of the examined EAE sections. A score of $1=$ mild demyelination, 2 = moderate demyelination, $3=$ severe demyelination, and $4=$ very severe involving $>50 \%$ of white matter. Mann-Whitney $U$ test was used to evaluate statistical significance.

\section{Quantification of percentage demyelination after immunofluorescent staining}

The extent of demyelination was calculated in slides stained for MBP and DAPI. The percentage of the demyelinated area relative to the total white matter area within the lumbar spinal was determined by imaging cross sections at $4 \times$. The total area of demyelination and myelination was calculated in Image and converted to percentage demyelination (Tsiperson et al., 2013). Student's $t$ test was used to evaluate statistical significance.

\section{Quantitative real-time RT-PCR}

Quantitative real-time RT-PCR (qRT-PCR) was performed using total RNA extracted from lumbar spinal cord using Qiazol Reagent with RNeasy kit (Qiagen). cDNA was synthesized using 500 ng of total RNA with the iScript cDNA synthesis kit (Bio-Rad). Gene expression was analyzed using iTaq Universal SYBR Green Supermix (Bio-Rad) on a StepOne Plus Real-Time PCR System (Life Sciences). Samples were run in duplicate for each of the genes listed in Table 1 and normalized using the geometric mean of $\beta$-actin, HPRT, and GAPDH with a WT sample set as a reference. Fold induction was calculated as $2^{-\Delta \Delta \mathrm{Ct}}$ (Livak and Schmittgen, 2001). Melting curves were determined for every sample to ensure specificity of the amplicon.

\section{Flow cytometry}

To evaluate populations of immune cell subsets from $\mathrm{Gas}^{-/-}$and WT mice, single cell suspensions were prepared and flow cytometry was performed. Mice having clinical scores for 3-4 d were anesthetized and perfused with $20 \mathrm{ml}$ of cold PBS and spinal cords were isolated and injected with $3 \mathrm{ml}$ of digestion buffer consisting of serum-free RPMI1640 containing Roche Liberase Grade TL 0.3 Wunsch units/ml and 300 Kunitz units DNase I/ml using a syringe tipped with a $263 / 8$ gauge needle. The tissue was cut into small pieces and incubated at $37^{\circ} \mathrm{C}$ with $5 \% \mathrm{CO}_{2}$ for $30 \mathrm{~min}$. Using the rubber plunger from a $3 \mathrm{ml}$ syringe, spinal cords were dissociated through a 70 micron cell strainer (BD Falcon) submerged in digestion buffer. The single-cell suspension was centrifuged at $300 \times g$ for $10 \mathrm{~min}$ at $4^{\circ} \mathrm{C}$ and washed twice with a large volume of PBS and filtered one additional time using a 70 micron cell strainer. Cells were then washed with FACS buffer (PBS $+2 \%$ fetal calf serum + $0.05 \%$ sodium azide) and blocked with mouse anti-Fc $\gamma$ RII/III (clone
Table 1. qRT-PCR primer pairs

\begin{tabular}{|c|c|c|}
\hline Gene & Forward & Reverse \\
\hline$A x \mid$ & 5'-ATGGCCGACATTGCCAGTG-3' & 5'-CGGTAGTAATCCCCGTTGTAGA-3' \\
\hline$\beta$-actin & 5'-GGCTGTATTCCCCTCCAATCG-3' & 5'-CCAGTTGGTAACAATGCCATGT-3' \\
\hline$C(R 2$ & 5'-ATCCACGGCATACTATCAACATC-3' & 5'-CAAGGCTCACCATCATCGTAG-3' \\
\hline CD68 & 5'-TGTCTGATCTTGCTAGGACCG-3' & 5'-GAGAGTAACGGCCTTTTTGTGA-3' \\
\hline$C \times 3 C R 1$ & 5'-TACCTTGAGGTTAGTGAACGTCA-3' & 5'-CGCTCTCGTTTTCCCCATAATC-3' \\
\hline GAPDH & 5'-CGTCCCGTAGACAAAATGGT-3' & 5'-TTGATGGCAACAATCTCCAC-3' \\
\hline HPRT & 5'-AGTCCCAGCGTCGTGATTAG-3' & 5'-TTTCCAAATCCTCGGCATAATGA-3' \\
\hline$I F N-\gamma$ & 5'-TCAAGTGGCATAGATGTGGAAGAA-3' & 5'-TGGCTCTGCAGGATTTTCATG-3' \\
\hline$I L-2$ & $5^{\prime}$-CCCAAGCAGGCCACAGAATTGAAA-3' & $5^{\prime}$-TGAGTCAAATCCAGAACATGCCGC-3' \\
\hline IL-4 & 5'-GGTCTCAACCCCCAGCTAGT-3' & 5'-GCCGATGATCTCTCTCAAGTGAT-3' \\
\hline IL-6 & $5^{\prime}$-CAGAGGATACCACTACCAACAG-3' & 5'-TCTCATTTCCACCACGATTTCCC-3' \\
\hline IL-10 & 5'-GCTCTTACTGACTGGCATGAG-3' & 5'-CGCAGCTCTAGGAGCATGTG-3' \\
\hline IL-13 & 5' -CCTGGCTCTTGCTTGCCTT-3' & 5'-GGTCTTGTGTGATGTTGCTCA-3' \\
\hline $\mid L-17$ & $5^{\prime}$-CAGCAGCGATCATCCCTCAAAG-3' & 5'-CAGGACCAGGATCTCTTGCTG-3' \\
\hline Mertk & $5^{\prime}$-CAGGGCCTTTACCAGGGAGA-3' & 5'-TGTGTGCTGGATGTGATCTTC-3' \\
\hline$M C P-1$ & 5'-GTATGTCTGGACCCATTCCTTC-3' & $5^{\prime}$-GCTGTAGTTTTTGTCACCAAGC-3' \\
\hline$M I P-1 \alpha$ & 5'-CAGCCAGGTGTCATTTTCCT-3' & 5'-AGGCATTCAGTTCCAGGTCA-3' \\
\hline Olig2 & 5'-TCCCCAGAACCCGATGATCTT-3' & $5^{\prime}$-CGTGGACGAGGACACAGTC-3' \\
\hline PDGFR $\alpha$ & 5' -AGAGTTACACGTTTGAGCTGTC-3' & 5'-GTCCCTCCACGGTACTCCT-3' \\
\hline Pros1 & 5'-CGCTTTCGGGTGCTACTGG-3' & 5'-CACTCTCGTTCAAGGTTGCC-3' \\
\hline RANTES & 5'-AGCTGCCCTCACCATCATC-3 & 5'-CTCGGGTTGGCACACACTT-3' \\
\hline SOCS1 & 5'-CTGCGGCTTCTATTGGGGAC-3' & 5'-AAAAGGCAGTCGAAGGTCTCG-3' \\
\hline SOCS3 & 5'-ATGGTCACCCACAGCAAGTTT-3' & 5'-TCCAGTAGAATCCGCTCTCCT-3' \\
\hline Sox10 & $5^{\prime}$-GAAGCCCCACATCGACTTCG-3' & 5'-GGCAGGTATTGGTCCAGCTC-3' \\
\hline TGF- $\beta 1$ & 5'-ACCATGCCAACTTCTGTCTG-3' & 5'-CGGGTTGTGTTGGTTGTAGA-3' \\
\hline$T N F-\alpha$ & 5'-TGAACTTCGGGGTGATCGGTC-3' & 5'-AGCCTTGTCCCTTGAAGAGAAC-3' \\
\hline Tyro3 & 5'-GCCTCCAAATTGCCCGTCA-3' & $5^{\prime}$-CCAGCACTGGTACATGAGATCA-3' \\
\hline
\end{tabular}

2.4G2) for $30 \mathrm{~min}$ at $23^{\circ} \mathrm{C}$ and surface stained with anti-CD68 (PerCP/ Cy5.5 clone FA-11) and anti-CD25 (PE/Cy7 clone PC61) purchased from BioLegend, anti-CD45 (PE clone 30F11), and anti-CD11c (APC clone N418) purchased from eBioscience, anti-CD4 (APC-H7 clone GK1.5), anti-CD11b (Alexa Fluor 700 clone M1/70), anti-CD45R/B220 (PE-Cy5 clone RA3-6B2), and anti-CD44 (FITC clone IM7) purchased from BD Pharmingen. For intracellular transcription factor staining, cells were fixed and permeabilized using the eBioscience FoxP3 staining kit according to the manufacturer's instructions and stained with antiFoxP3 (eFluor 450 clone FJK-16s) and anti-ROR $\gamma \mathrm{t}$ (PE-CF594 clone Q31-378) purchased from eBioscience. Samples were acquired on an LSR II flow cytometer using FACSDiva software (BD Biosciences) and analysis was performed using FlowJo software (TreeStar). Compensation was calculated by FACSDiva software before sample acquisition using anti-mouse Ig, $\kappa$ or anti-rat/hamster Ig, $\kappa$ CompBead Plus (BD Biosciences) compensation beads singly stained with the appropriate fluorophore-conjugated antibodies. For the identification of leukocytes, aggregates were excluded from analysis by gating on cells with equivalent FSC-H/FSC-A and low SSC-W/SSCA profiles. Activated T cells were identified by gating on $\mathrm{CD}^{+}{ }^{+}$cells expressing the activation markers CD25 and CD44. Activated T cells were then identified as Tregs or Th17 by expression of master transcription factors FoxP3 or ROR $\gamma \mathrm{t}$, respectively. B cells were identified as CD11 $\mathrm{c}^{-} \mathrm{CD} 11 \mathrm{~b}^{-} \mathrm{CD} 45 \mathrm{R} / \mathrm{B} 220^{+}$. Microglia and macrophages were identified by gating on cells negative for both $\mathrm{CD} 4$ and B220 and positive for CD11b. Macrophages were defined as $\mathrm{CD} 68^{+} \mathrm{CD} 45^{\text {hi }}$ and microglia as $\mathrm{CD} 45^{\text {int }}$ with variable CD68 expression reliant on activation state.

\section{Statistical analysis}

Statistical analysis was performed with GraphPad Prism version 6.02 software. To analyze significance during EAE, a Mann-Whitney $U$ test was performed on the clinical indices at each time point. Significance for relative scales, such as Iba1 and CD3 inflammatory score and MBP relative demyelination, were assessed for significance by the Mann-Whitney $U$ test. Student's $t$ test was performed for parametric two-group comparisons. Error is represented as SEM. 
A

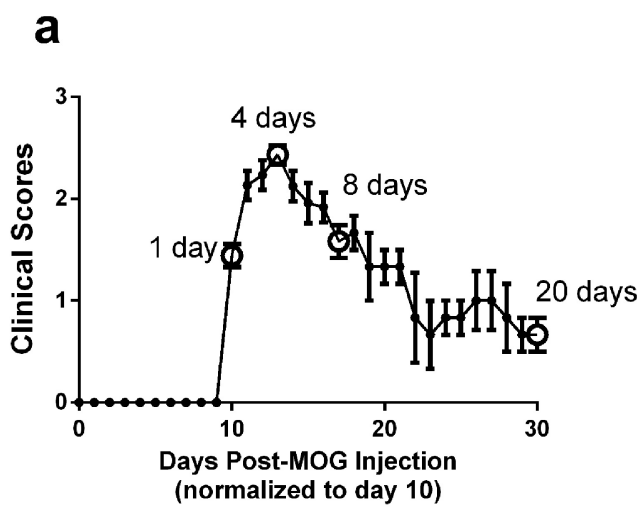

b

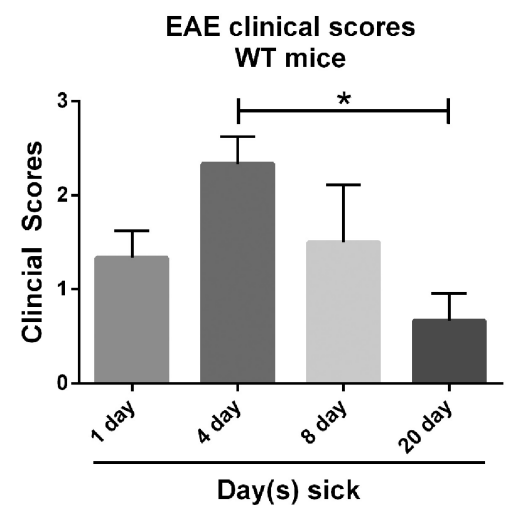

B

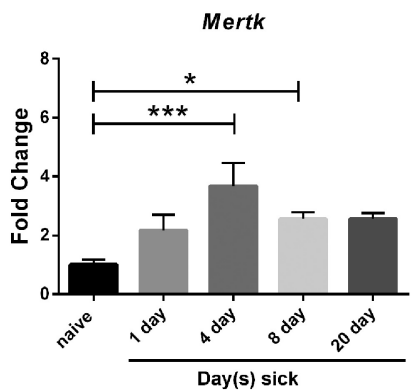

E

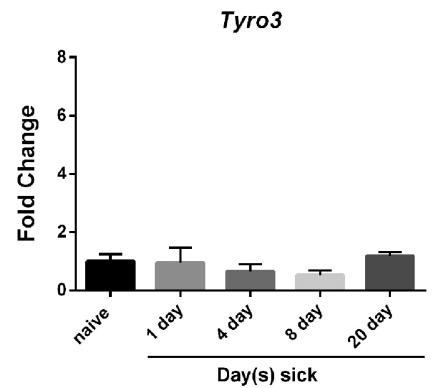

C

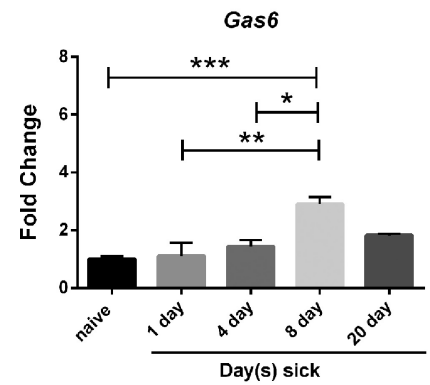

D

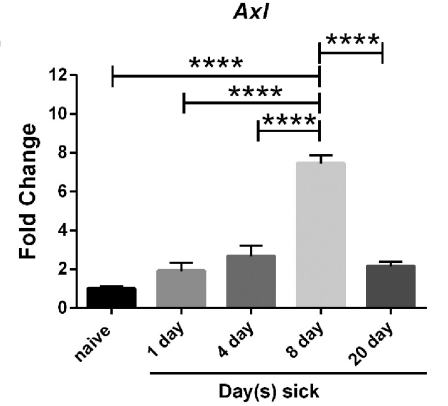

$\mathbf{F}$

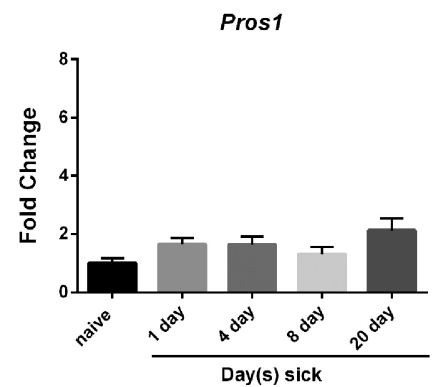

Figure 1. Gas6, Axl, and Mertk, but not Tyro3 or Pros1, mRNA are significantly induced in the lumbar spinal cord during EAE. Aa, EAE clinical scores of mice used for qRT-PCR analysis. Open circles represent the scores and days the animals were removed for RNA isolation and analysis. $\boldsymbol{A b}$, Mean clinical scores ( $(\mathrm{C} \pm \mathrm{SEM})$ of the mice on the day of kill; first day sick is considered the first day mice had a $\mathrm{Cl} \geq 1$. Days are counted consecutively thereafter regardless of score. The scores of the mice on each day is as follows: first day sick $(n=3, \mathrm{Cl}=1.3 \pm 0.17), 4 \mathrm{~d}$ sick $(n=3, \mathrm{Cl}=2.3 \pm 0.17)$, $8 \mathrm{~d}$ sick $(n=9, \mathrm{Cl}=1.5 \pm 0.2), 20 \mathrm{~d}$ sick $(n=3, \mathrm{Cl}=0.67 \pm 0.17)$, and naive not shown $(n=4, \mathrm{Cl}=0)$. There was a significant reduction in the clinical scores from day $4-20$ with $\mathrm{Cl}(p<0.05$, Kruskal Wallis one-way ANOVA). $\boldsymbol{B}-\boldsymbol{F}$, Fold change reflects EAE value normalized to the value of naive mice (black) shown on the $y$-axis scale as $1 . \boldsymbol{B}$, Mertk mRNA was significantly increased in the spinal cords of mice with clinical scores for $4 \mathrm{~d}(p<0.001)$ and $8 \mathrm{~d}(p<0.05)$ relative to naive spinal cords. C, Gas $6 \mathrm{mRNA}$ is significantly increased in spinal cords of mice with clinical scores for $8 \mathrm{~d}$ relative to naive $(p<0.001)$ and relative to spinal cords with a score for $1 \mathrm{~d}(p<0.01)$ and $4 \mathrm{~d}(p<0.05)$. D, Axl is significantly increased at day 8 relative to naive spinal cord and relative to all other time points $(p<0.0001)$. $\boldsymbol{E}, \boldsymbol{F}$, Tyro3 and Pros $1 \mathrm{mRNA}$ are not significantly changed relative to naive spinal cord and all time points examined. One-way ANOVA was used for mRNA statistical comparisons $(\boldsymbol{B}-\boldsymbol{F})$.

\section{Results}

Gas6, Axl, and Mertk RNA, but not Tyro3 or Pros1 mRNA, are significantly increased in WT mice during EAE

To determine whether Gas6 expression increases during EAE and might be beneficial for treatment, we sensitized WT mice with $\mathrm{MOG}_{35-55}$ peptide and examined Gas6, Pros1, and TAM receptor mRNA expression during EAE relative to naive mice. qRT-PCR analysis of TAM receptor and ligand expression was performed in naive WT mice and WT mice with clinical scores for $1,4,8$, and 20 consecutive days of EAE. Figure $1 A$ illustrates the mean clinical course of the MOG-sensitized WT mice throughout EAE. The day one time point represents the first day mice had clinical scores. Additional time points include peak acute EAE (day 4), late acute EAE (day 8), and chronic EAE (day 20). Mice with clinical scores for 20 consecutive days ( $\sim$ day 30 EAE) had a sig- nificant reduction in scores relative to mice with clinical scores for 4 consecutive days $(p<0.05)$, indicating that significant recovery had taken place over that time. Figure $1 B$ shows that Mertk was significantly increased in mice with clinical scores for $4 \mathrm{~d}$ $(p<0.001)$ and $8 \mathrm{~d}(p<0.05)$, correlating with the influx in monocyte/macrophages and glial activation. Figure $1 C$ shows that, relative to naive mice, there was a significant increase in Gas6 mRNA in mice with scores for 8 consecutive days $(p<$ $0.001)$. Although not significant by one-way ANOVA, $A x l$ expression increased 1.9-fold and 2.6-fold after 1 and $4 \mathrm{~d}$ sick, respectively (Fig. 1D). Axl expression was significantly elevated in mice sick for $8 \mathrm{~d}$ relative to naive with a $7.5 \pm 0.42$-fold increase $(p<0.0001$, one-way ANOVA). We found no significant changes in Tyro3 at any time point examined (Fig. 1E). Pros 1 was not significantly increased at any of the time points examined 
A

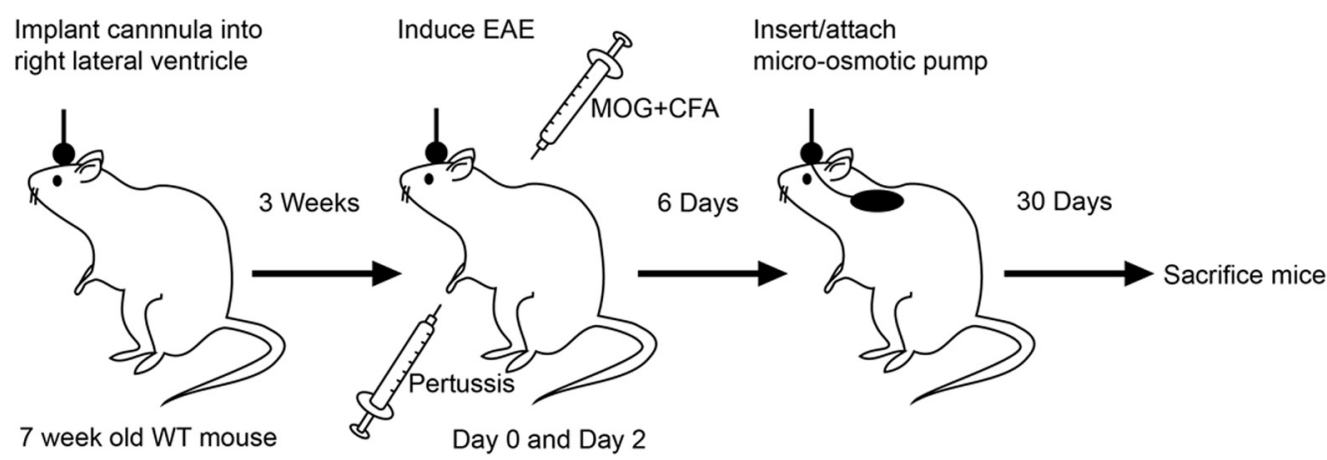

B

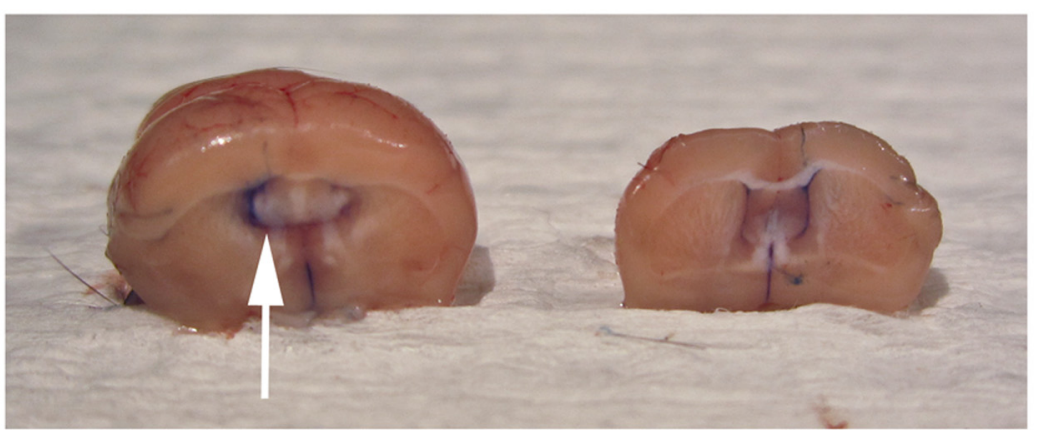

C

MOG-Induced EAE: Micro-osmotic pumps

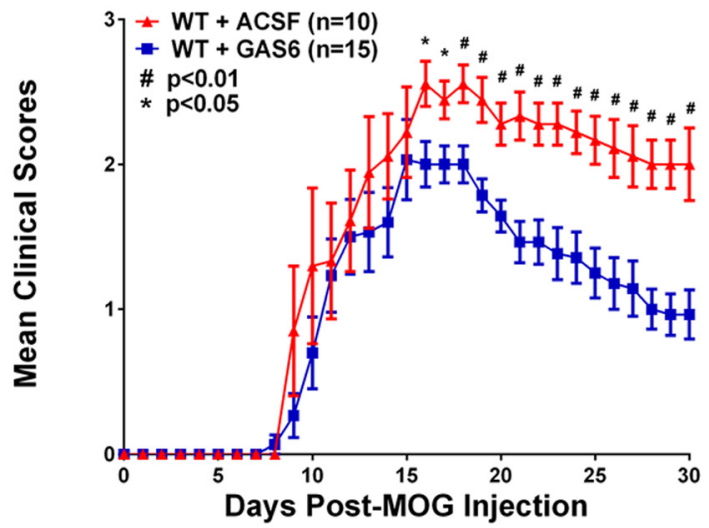

Figure 2. GAS6 directly administered to the lateral ventricle by cannula/micro-osmotic pump significantly reduced the clinical score of WT mice during acute and chronic EAE. $A$, Schematic illustrating cannula implantation into the right lateral ventricle of $\mathrm{C} 57 \mathrm{BL} / 6 \mathrm{~J}$ mice before induction of EAE. A cannula was inserted into the lateral ventricle of 7-week-old mice at the coordinates $0.4 \mathrm{~mm}$ posterior to bregma, $1.0 \mathrm{~mm}$ lateral right, $2.5 \mathrm{~mm}$ ventral to skull surface (see Materials and Methods). All mice were monitored for 3 weeks after surgery to ensure that the mice were healthy before inducing EAE. Six days after the second Ptx injection, the pump was inserted under the skin at the scapula and connected to the cannula. $\boldsymbol{B}$, ACSF + India ink administered via cannula implanted at our coordinates demonstrates circulation through the ventricles. Arrow indicates blue dye in the ventricle. $\boldsymbol{C}$, Clinical scores of mice during acute and chronic EAE. Mean clinical scores of ACSF-treated mice $(n=10)$ and GAS6-treated mice $(n=15)$. \#p $\leq 0.01 ;{ }^{*} p \leq 0.05$, Mann-Whitney $U$ test. There was no difference in the day of onset of clinical scores in the two groups of mice.

(Fig. 1F). Induction of Gas6 and Axl during the transition from late acute to chronic phase of EAE suggests that these genes may aid in recovery. Our data are consistent with a report showing Axl is important for resolution of inflammation (Zagórska et al., 2014). Based upon these data that Gas6 and TAM receptors are induced during EAE and our previous study demonstrating that administration of GAS6 enhances recovery from cuprizone toxicity (Tsiperson et al., 2010), we initiated studies to determine whether treatment with GAS6 would be beneficial during EAE.
Direct CNS administration of GAS6 is protective during acute and chronic EAE

After our previous success using intracerebral delivery of GAS6 in the cuprizone model, we investigated whether sustained administration of GAS6 via intracerebroventricular cannula and microosmotic pump would be beneficial during acute and chronic EAE. As shown in the schematic in Figure $2 A$, a cannula was inserted into the lateral ventricle of female mice. Figure $2 B$ shows that administration of ACSF plus India ink through a cannula 
A
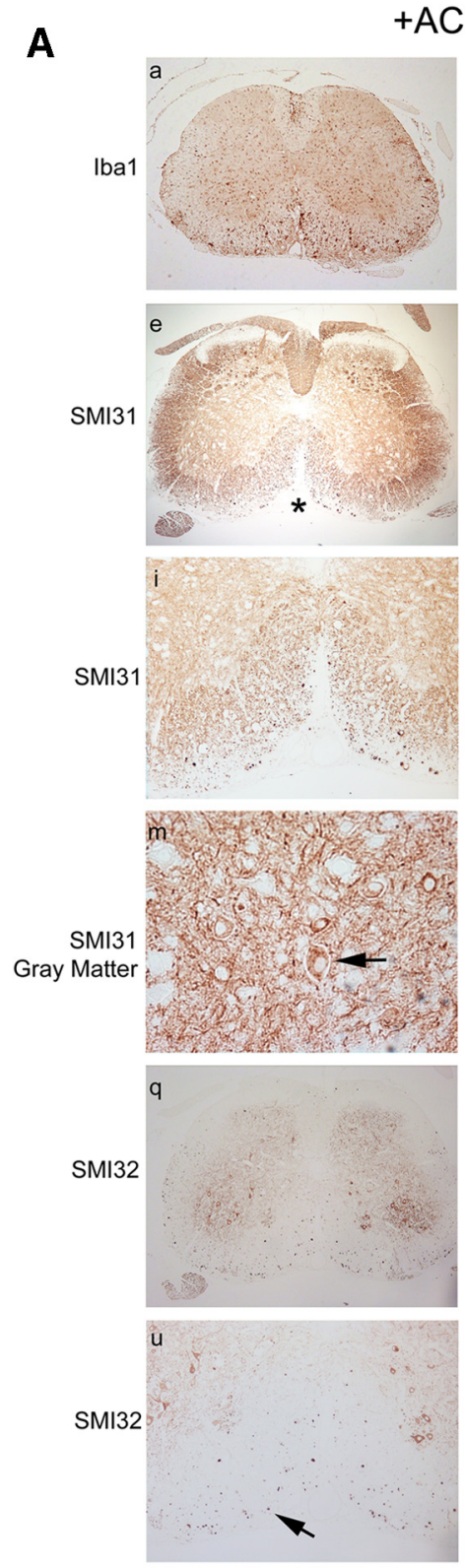

ACSF
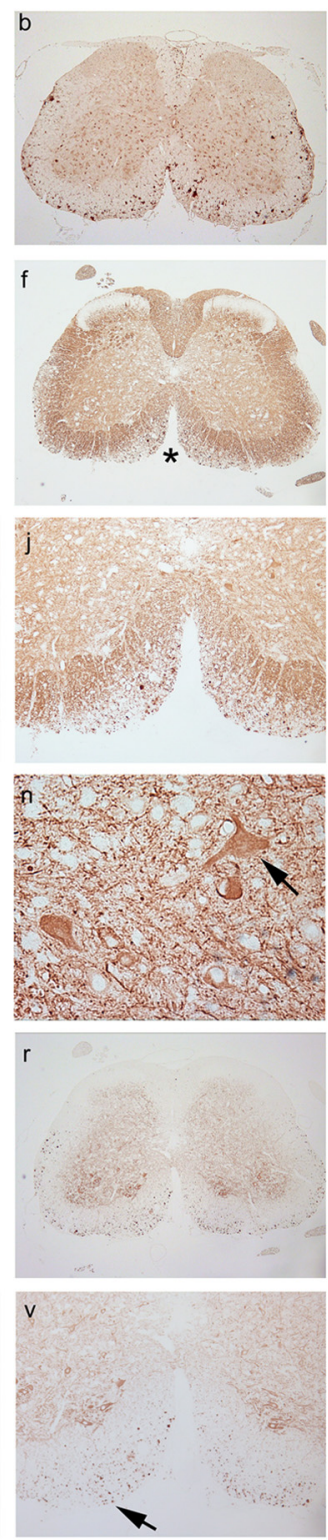

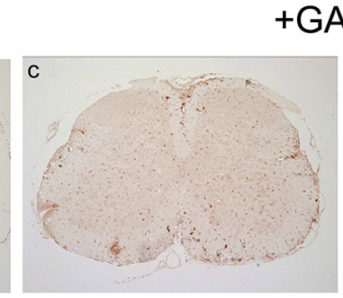

+GAS6
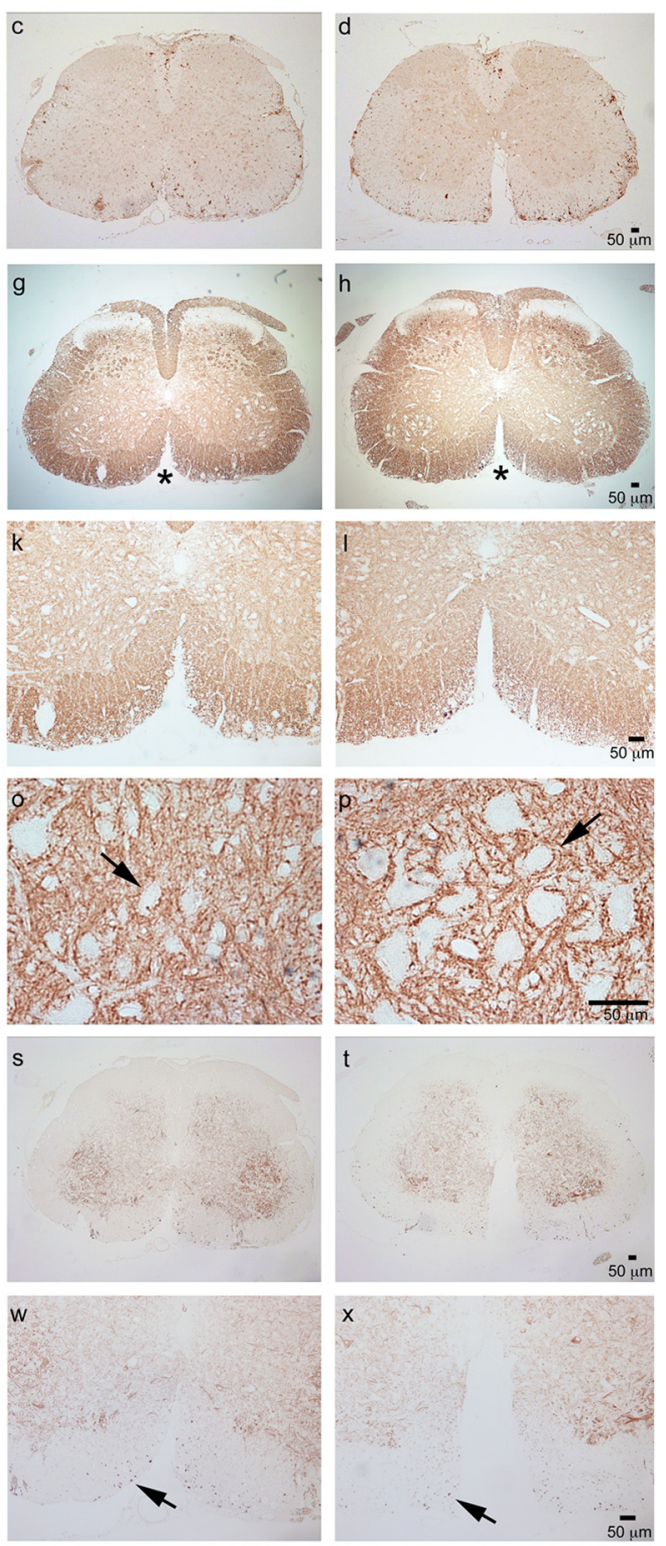

B

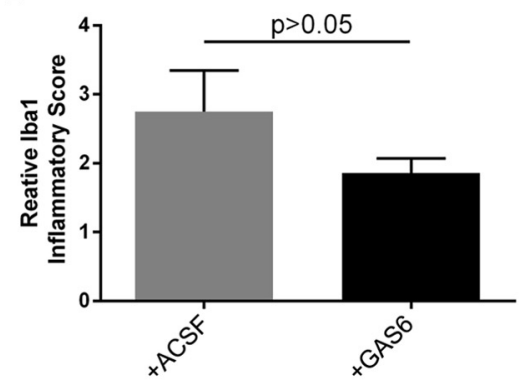

C

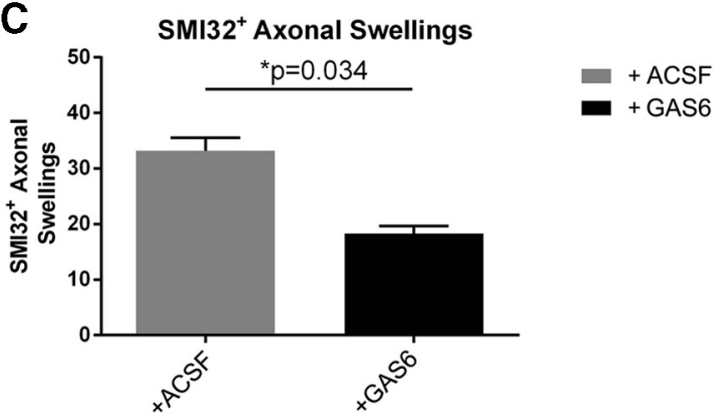

Figure 3. GAS6 treatment significantly reduced the number of SMI32 ${ }^{+}$-damaged axons, but did not significantly reduce the relative lba ${ }^{+}$inflammatory scores relative to ACSF-treated mice. $\boldsymbol{A a}-\boldsymbol{A x}$, Two representative sections from ACSF-treated $(n=4)$ and GAS6-treated $(n=7)$ mice are depicted. All bars are $50 \mu \mathrm{m}$. $\boldsymbol{A} \boldsymbol{a}$ - $\boldsymbol{A d}$, Iba1 immunostaining quantified in $\boldsymbol{B}$. GAS6-treated mice trended toward fewer Iba ${ }^{+}$-activated macrophages/microglia; however, the relative inflammatory scores were not significantly different $\left(p>0.05\right.$, Mann-Whitney $U$ test). The extent of $\mid \mathrm{ba} 1^{+}$

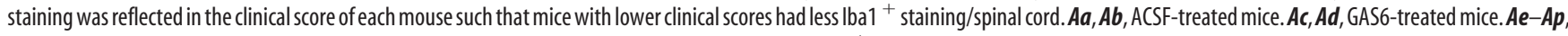
SMI31 immunostaining. $\boldsymbol{A} \boldsymbol{q}-\boldsymbol{A x}, \mathrm{SMI32}$ immunostaining. $\boldsymbol{A e}-\boldsymbol{A x}$, GAS6-treated mice have more SMI31 ${ }^{+}$axons $(\boldsymbol{A g}, \boldsymbol{A h}, \boldsymbol{A k}, \boldsymbol{A l})$, less neuronal cell body staining in gray matter $(\boldsymbol{A o}, \boldsymbol{A p})$, and significantly fewer SMI32 ${ }^{+}$axonal swellings ( $\left.\boldsymbol{A s}, \boldsymbol{A t}, \boldsymbol{A w}, \boldsymbol{A x}\right)$ than ACSF-treated mice $(\boldsymbol{A i}, \boldsymbol{A j}, \boldsymbol{A m}, \boldsymbol{A n}, \boldsymbol{A q}, \boldsymbol{A r}, \boldsymbol{A u}, \boldsymbol{A v})$. Asterisk in $\boldsymbol{A e}-\boldsymbol{A h}$ denote ventral spinal cord region shown at higher magnification in $\boldsymbol{A i}-\boldsymbol{A l}$. Note the presence of SMI31 ${ }^{+}$immunoreactivity in the cell body of ACSF neurons within gray matter $(\boldsymbol{A m}, \boldsymbol{A n} ; \times 400)$ and clear SMI31 ${ }^{-}$neurons in GAS6-treated mice $(\boldsymbol{A o}$, $A \boldsymbol{p}$; arrows). Arrows in $\mathbf{A u}-\mathbf{A x}$ indicate SMI32 ${ }^{+}$swellings in the ventral spinal cord. $\boldsymbol{B}$, Quantification of Iba ${ }^{+}$glia in lumbar spinal cord; the mean scores for the two (Figure legend continues.) 
placed at the designated coordinates illustrates that the dye efficiently reached the lateral and third ventricles. GAS6-loaded (4 $\mu \mathrm{g} / \mathrm{ml}$ ) or ACSF-loaded pumps were attached to the cannulae $6 \mathrm{~d}$ after the second Ptx injection and mice were examined after 25-28 d of treatment; therefore, all histological analyses were performed on mice during chronic EAE.

As shown in Figure 2C, compared with the ACSF-treated mice, GAS6 treatment did not alter the day of onset of disease or the initial clinical course up to day 15 . From days 16-30, there was a statistically significant decrease in the clinical scores of the GAS6-treated mice relative to the ACSF-treated mice representing peak disease $(p<0.05)$ and throughout the chronic phase $(p<0.01$, Mann-Whitney $U$ test $)$.

Consistent with a significant difference in the clinical scores during chronic EAE, we observed a decrease in the overall number of Iba1 ${ }^{+}$cells/spinal cord in the GAS6-treated mice relative to the ACSF-treated WT mice (Fig. $3 A, B$ ). Figure $3 A$ shows representative lumbar spinal cord sections from two ACSF-treated (Fig. 3Aa, $A b$ ) and two GAS6-treated (Fig. 3Ac, Ad) immuostained for Iba1. Figure $3 B$ shows the mean Ibal scores for the two groups of mice based upon a 1-4 scale. The mean Iba $1^{+}$inflammatory score of the ACSF-treated mice was higher but was not significantly different, because one ACSF-treated mouse had minimal Ibal staining and a GAS6-treated mice had a mean Ibal score of 2.5 ( $p>0.05$; Mann-Whitney $U$ test). In a second study with independent groups of GAS6- and ACSF-treated mice, there was also no significant difference in the Ibal inflammatory score and pooling the data from the two experiments was also not significant, indicating mouse to mouse variability in monocyte/macrophage/microglial activation at the chronic endpoint. Quantification of T-cell infiltration by CD3 immunostaining did not demonstrate a significant difference in the relative scores (data not shown).

Immunohistochemical staining using mAbs specific for phosphoneurofilament (SMI31) and non-phospho-neurofilament (SMI32) protein and light microscopy showed that there was significantly less axonal damage in the lumbar spinal cord of GAS6-treated mice relative to the ACSF-treated mice (Fig. $3 A e-A x$ ). To confirm that increased axonal swelling coincided with reduced axonal integrity, we stained spinal cord sections with SMI31, an antibody that recognizes phosphorylated neurofilament protein in healthy axons. Figure 3, $A e-A l$, shows staining for SMI31 at low (Fig. 3Ae$A h ; \times 5)$ and high magnification (Fig. $3 A i-A l ; 100 \times$ objective). Cross-sections of the lumbar spinal cord show less SMI31 immunoreactivity in the white matter of the ventral spinal cord of ACSFtreated mice (Fig. $3 A e, A f$ ) relative GAS6-treated mice (Fig. 3Ag,Ah; $5 \times$ objective). Two representative mice from each group are depicted (Fig. $3 A e-A h$; asterisk in each panel illustrates the ventral white matter region shown at high magnification in Fig. $3 A i-A l$ ).

The presence of $\mathrm{SMI} 31^{+}$phosphorylated neurofilament protein in the neuronal cell body is as an indicator of neuronal cell

(Figure legend continued.) groups of mice based upon a 1-4 scale: Iba ${ }^{+}$cells were scored on a 1- 4 inflammatory scale where $1=$ mild inflammation at lesions, $2=$ moderate inflammation at lesions, $3=$ severe inflammation at lesions, and $4=$ very severe inflammation involving 50\% or more of the spinal cord (Tsiperson et al., 2013; Mann-Whitney $U, p>0.05$ ). The mean relative $\mathrm{Iba}^{+}{ }^{+}$inflammatory score of the ACSF-treated mice $(n=4)$ was $2.75 \pm 0.60$ the mean score for the GAS6-treated mice $(n=7)$ was $1.86 \pm 0.21(p>0.05)$. C, Graph of the mean number of SMl32 ${ }^{+}$axonal swellings $(>3 \mu \mathrm{m}$ ) in multiple $20 \times$ fields for the left and the right ventral region of the lumbar spinal cord of ACSF and ACSF + Gas6-treated mice. The SMI32 ${ }^{+}$swellings for the ACSF-treated mice $(n=4)$ were $33.2 \pm 4.6$ and $18.3 \pm 3.6$ for the GAS6-treated mice $(n=7), p=0.034$. body injury. Figure 3, $A m-A p$, shows that there are significantly more SMI $31^{+}$motor neuron cell bodies within the gray matter of the ACSF-treated mice, $8.56 \pm 3.45$ (Fig. $3 A m, A n$; arrows, $40 \times$ ), than in the GAS6-treated mice, $1.67 \pm 0.88(p=0.033$, Student's $t$ test; Fig. $3 A o, A p)$. In contrast to the $\mathrm{SMI} 31^{+}$axonal immunostaining, we observed that ACSF-treated mice had more $>3 \mathrm{mi}$ cron SMI $32^{+}$axonal swellings in the ventral region of the spinal cord (Fig. 3Aq,Ar,Au,Av) than the GAS6-treated mice (Fig. $3 A s, A t, A w, A x)$. The arrows in Figure $3, A u-A x$, refer to $>3$ micron swellings observed at higher magnification $(20 \times)$. We quantified the number of SMI $32^{+}$axonal swellings in multiple $20 \times$ fields for the left and the right ventral region of white matter from ACSF- and GAS6 treated mice. As demonstrated in Figure $3 C$, we found significantly fewer SMI $32^{+}$swellings in the GAS6treated mice $(n=7)$ relative to the ACSF-treated mice $(n=4)$ ( $p=0.034$, Student's $t$ test). Additional analysis of APP ${ }^{+}$axonal staining showed no significant increase in $\mathrm{APP}^{+}$spheroids in the ventral spinal cord of the two groups of mice (data not shown). It is known that APP immunostaining within axons is indicative of fast axonal transport defects is transient and best observed during early stages of axonal damage, often not coinciding with SMI $32^{+}$ swellings (Soulika et al., 2009).

While quantifying the number of $\mathrm{SMI}_{3}{ }^{+}$swellings, we detected a large number of dystrophic $(>10 \mu \mathrm{m}) \mathrm{SMI}_{32}{ }^{+}$axonal spheroids (Fig. $4 A a$, arrow). To quantify those specifically and to quantify demyelination, we performed immunofluorescent staining on the treated spinal cords. In Figure $4 A$, we show double-label immunofluorescent staining of spinal cord sections from three different ACSF-treated (Fig. 4Aa,Ae,Ai) and GAS6treated (Fig. 4Ac, $A g, A k$ ) mice with antibodies to SMI32 (red) and MBP (green) by fluorescent microscopy $(10 \times)$. The asterisk refers to the area of $60 \times$ magnification in Figure 4, $A b, A f, A j$ and $A d, A h, A l$. Using Volocity image analysis software (PerkinElmer), we quantified the number and size of $\mathrm{SMI}_{3} 2^{+}$swellings from $40 \times$ images spanning the ventral lumbar spinal cord. We found significantly more axonal swellings $>3 \mu \mathrm{m}(p<0.05)$ and dystrophic axons $>10 \mu \mathrm{m}(p=0.012)$ in ACSF-treated mice $(n=7)$ relative to GAS6-treated mice $(n=10)$ (Fig. $4 B)$. Next, we quantified the relative amount of MBP immunoreactivity for the 2 treated groups using a 1-4 scale (Fig. $4 C$ ). We observed significantly more MBP immunoreactivity in the ventral region of the lumbar spinal cord of GAS6-treated mice $(n=10)$ relative to ACSF-treated mice $(n=7), p=0.02$ (Fig. $4 C$ ). In addition, the extent of demyelination was calculated as a percentage of the demyelinated area relative to the total white matter area within the lumbar spinal cord as described in Materials and Methods. We found significantly less demyelination in the GAS6-treated mice $(n=10)$ than in control ACSF-treated mice $(n=7 ; p=$ 0.012 , Student's $t$ test; Fig. $4 D$ ). Our data indicate that there was less demyelination and/or enhanced remyelination in spinal cords treated with GAS6 relative to controls.

\section{IFN $\beta$ administered by subcutaneous injection to GAS6- treated mice fails to further reduce the clinical score of GAS6- treated mice}

In the Prevention of Relapses and Disability by Interferon $\beta$-1a Subcutaneously in Multiple Sclerosis (PRISMS) study of 1998, IFN $\beta$ was found to be therapeutic for delaying the time between episodes and is now used by individuals with relapsing remitting MS. In the context of our GAS6 regimen, we investigated whether a subcutaneous IFN $\beta$ injection (Betaseron; Bayer) on alternate days commencing $7 \mathrm{~d}$ after the second Ptx injection would further reduce the clinical scores of mice receiving GAS6 and ACSF. 
A
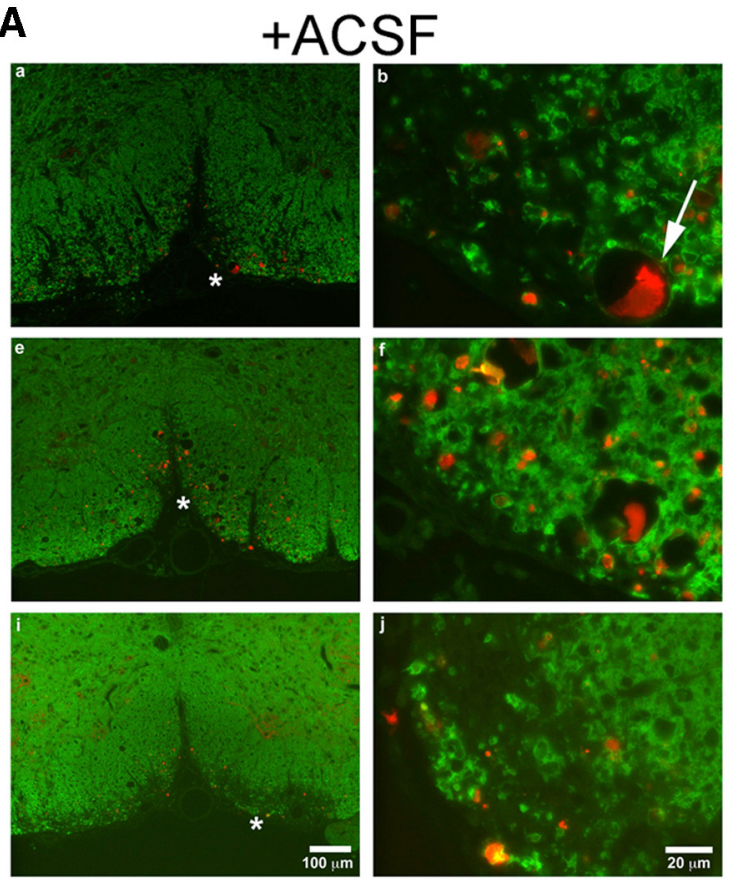

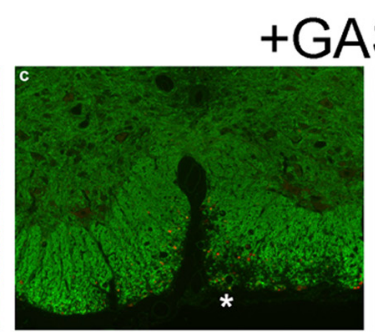

S6
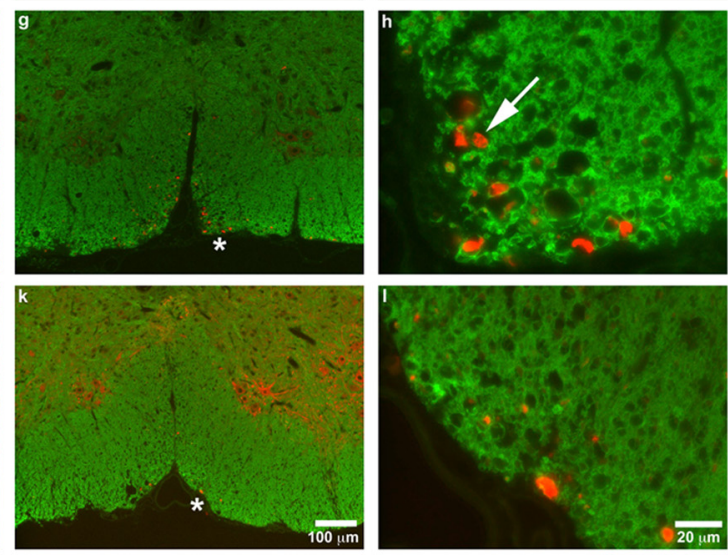

B

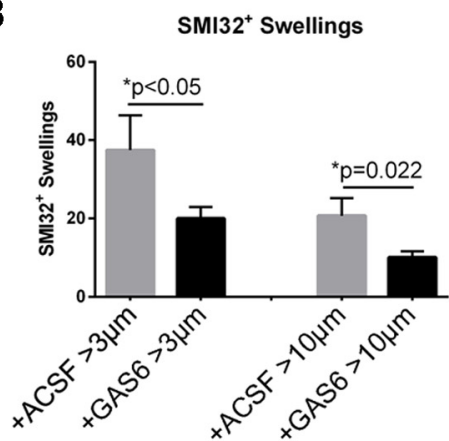

C
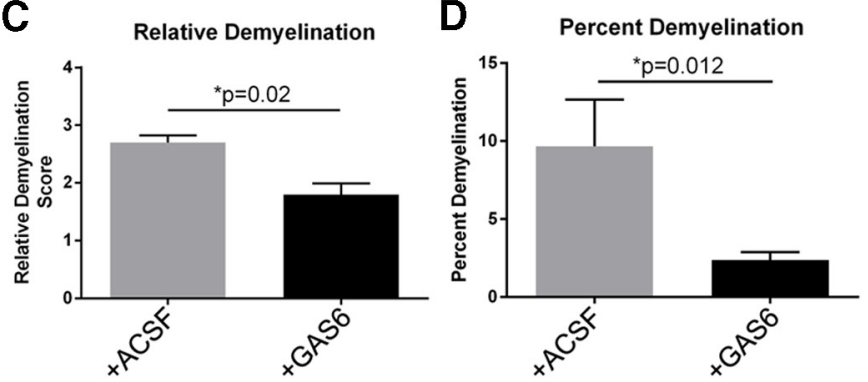

Figure 4. GAS6 treatment results in significantly less demyelination and fewer damaged axons. $\boldsymbol{A}$, Lumbar spinal cord sections from ACSF- (Aa, $\boldsymbol{A} \boldsymbol{b}, \boldsymbol{A e}, \boldsymbol{A f}, \boldsymbol{A i}, \boldsymbol{A j})$ and GAS6-treated mice $(\boldsymbol{A c}, \boldsymbol{A d}$, $\boldsymbol{A g}, \boldsymbol{A h}, \boldsymbol{A k}, \boldsymbol{A} \boldsymbol{l}$ ) were stained for nonphosphorylated neurofilament protein using mAb SMI $32^{+}$(red) and for MBP (green) and examined by fluorescence microscopy at both $20 \times$ and $60 \times$. Arrow denotes axonal spheroid $(\boldsymbol{A} \boldsymbol{b})$ and axonal swellings $(\boldsymbol{A d})$. $\boldsymbol{B}$, Volocity quantification of SMI32 ${ }^{+}$axonal swellings $>3 \mu \mathrm{m}$ and dystrophic axons $>10 \mu \mathrm{m}$. The number of SMI32 ${ }^{+}$axonal swellings $>3 \mu \mathrm{m}$ was significantly lower in GAS6-treated mice $19.98 \pm 3.010(n=10)$ versus ACSF-treated $37.48 \pm 8.907(n=7), p<0.05$ (Student'st test); similarly, the number of SMI32 ${ }^{+}$axons $>10$ $\mu \mathrm{m}$ was significantly lower in GAS6-treated mice $2.380 \pm 0.4982(n=10)$ than in ACSF-treated mice $9.658 \pm 3.017(n=7)(p=0.0123$, Student's $t$ test). C, Quantification of relative demyelination score by MBP immunoreactivity: a score of 0 is the equivalent of MBP immunoreactivity observed in naive ventral spinal cord; we did not observe this in any of our treated sections. A score of 1 = mild demyelination, $2=$ moderate demyelination, $3=$ severe demyelination, and $4=$ very severe involving greater that $50 \%$ of white matter. Before quantification, slide identity was masked to the reviewer and at least 3 sections of lumbar spinal cord/specimen were assessed by two individuals. Significantly more MBP immunoreactivity was observed in the ventral region of lumbar spinal cord of GAS6-treated mice $1.8 \pm 0.19(n=10)$ relative to ACSF-treated mice $2.7 \pm 0.32(n=7)(p=0.02$, Mann-Whitney $U$ test). $D$, The extent of demyelination was calculated as a percentage of the demyelinated area relative to the percentage of the total white matter area within the dorsal, ventral and lateral regions. The mean percentage of demyelination for the $+\mathrm{ACSF}$ mice was $9.658 \pm 3.02(n=7)$ and the mean percentage of demyelination for the + GAS6 mice was $2.380 \pm 0.50(n=10)(p=0.012$, Student's $t$ test).

GAS6-treated mice $(4 \mu \mathrm{g} / \mathrm{ml})$ had significantly reduced clinical scores relative to the ACSF-treated cohort. As demonstrated in Figure $5 A$, injection of IFN $\beta$ alone delayed the onset of EAE by $3 \mathrm{~d}$. When GAS6 + IFN $\beta$ treatment was compared with GAS6only treatment, the data showed that GAS6 was more effective at reducing clinical scores. The graph in Figure $5 B$ demonstrates that, within the groups of mice tested, the IFN $\beta+$ GAS6treatment did not significantly reduce axonal dystrophy. This study shows that, although IFN $\beta$ delayed the start of EAE, it could not protect against the axonal damage ultimately incurred during chronic disease and GAS6 + IFN $\beta$ did not result in a synergistic response. Because GAS6 affords better protection against axonal damage, no further IFN $\beta$ studies were explored.
Deletion of Gas6 enhances inflammation in spinal cord, increases clinical scores, and delays recovery from EAE Our current studies indicate that GAS6 is beneficial during EAE and predict that loss of GAS6 signaling would be detrimental during EAE. To determine whether deletion of Gas6 would exacerbate disease progression, WT and $\mathrm{Gas}^{-1-}$ mice were sensitized with MOG peptide and monitored over the course of EAE. Figure $6 A$ shows a graph compiled from six independent EAE experiments. There was no difference in the mean day of onset of clinical scores for the two groups of mice; therefore, the day of onset was normalized to day 10 for comparison. In this composite graph, there was a significant difference in clinical scores between WT and $\mathrm{Gas}^{-1-}$ mice beginning $4 \mathrm{~d}$ after the onset of 
A

\section{MOG-Induced EAE: Micro-osmotic pumps}

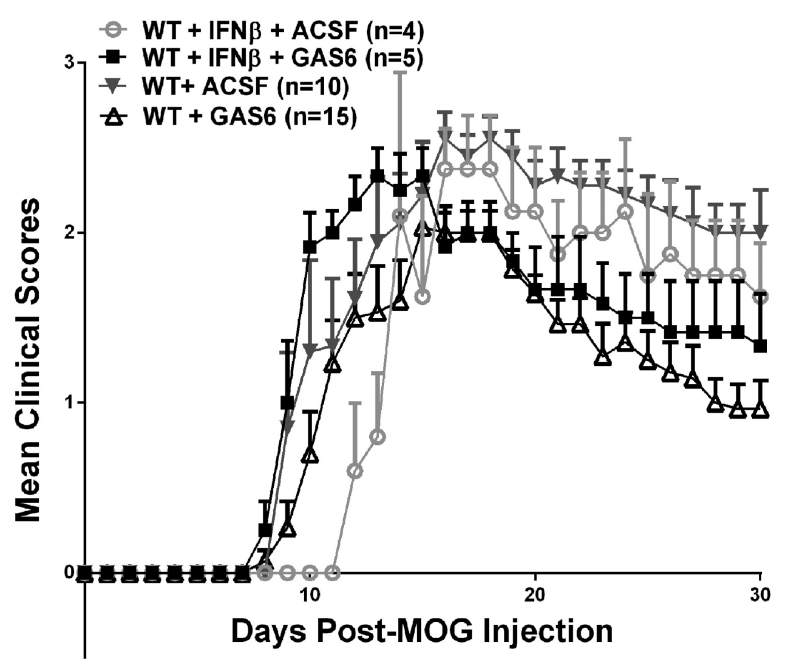

B

SMI $32^{+}$Axonal Swellings

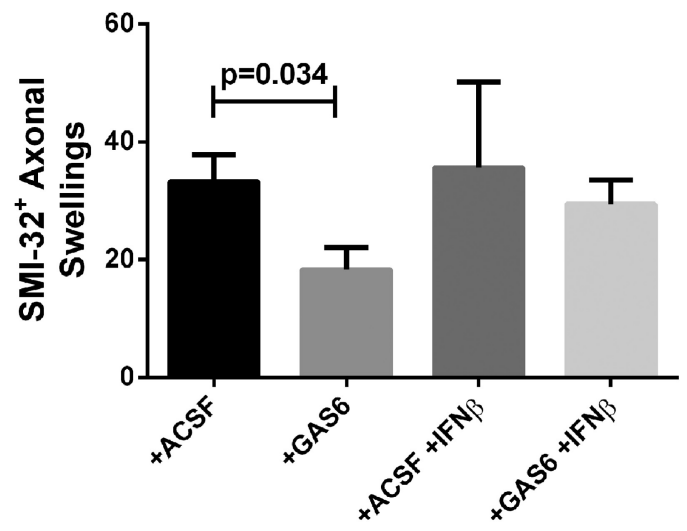

Figure 5. Subcutaneous (subQ) IFN $\beta$ injection was not beneficial in reducing the clinical scores during acute and chronic EAE in mice treated with ACSF or GAS6. $A$, Mice were given subQ injections of human IFN $\beta\left(3 \times 10^{4}\right.$ units, Betaseron) on alternate days commencing $7 \mathrm{~d}$ after the second Ptx injection. The groups consisted of WT mice treated with IFN $\beta+$ ACSF (open circle, $n=4$ ), IFN $\beta+$ GAS6 (closed square, $n=5$ ), + ACSF (inverted closed triangle, $n=10$ ), and + GAS6 (open triangle, $n=15$ ). $\boldsymbol{B}$, Quantification of SMI32 ${ }^{+}$axonal swelling in the ventral spinal cord of treated mice. IFN $\beta$ treatment did not result in a significant reduction of $\mathrm{SMI}^{2}{ }^{+}$swellings when administered with or without GAS6ICV.

clinical signs and continuing through the disease course (MannWhitney $U$ test). Among the six independent time courses, the first day in which we observed a significant difference in the mean clinical scores between the Gas6 $6^{-1-}$ and WT mice varied by 1-2 d, however, we consistently observed that the chronic course of disease was higher in the sensitized Gas $6^{-1-}$ mice. All mice included in the study had a clinical course. We found that $56.6 \%$ of $\mathrm{Gas}^{-1-}$ mice had hindlimb paralysis and scores $\geq 3$, whereas $31 \%$ of WT mice had scores of 3 during the course of disease. The percentage of mice having hindlimb paralysis and forelimb weakness/paralysis [Clinical Score/Clinical Index $(\mathrm{CI}) \geq 3.5]$ was $24 \%$ for $\mathrm{Gas}^{-1-}$ mice and $2.4 \%$ for the WT mice, indicating that there is a larger cohort of $\mathrm{Gas}^{-1-}$ animals that experience a more severe course than the WT mice. Because animals were removed at different times during the study for histologic/pathologic and molecular analyses, there were $20 \mathrm{WT}$ and $24 \mathrm{Gas}^{-1-}$ mice remaining on day 25 .

Immunocytochemical staining for Iba1 and CD3 within the spinal cord were evaluated for increased macrophage/microglia and T-cell infiltration, respectively (Fig. 6B,C). For this study, the mice were killed $20 \mathrm{~d}$ after the first Ptx injection and all mice in both groups had mean clinical scores for 8-12 d. The Gas $6^{-1-}$ mice $(n=6)$ had a mean score of 2.5 and the mean of WT mice $(n=7)$ was $1.3 ; p=0.005$ (Mann-Whitney $U$ test). The graph in Figure $6 \mathrm{Ba}$ and the staining in Figure $6, C b$ and $C f$, show that there was a significant increase in $\mathrm{Ibal}^{+}$glia in $\mathrm{Gas}^{-1-}$ mice relative to WT as assessed by the scale in Materials and Methods. The mean Ibal inflammatory score in spinal cord was significantly higher in the Gas6 $^{-/-}$mice $(3.33 \pm 0.22, n=6)$ relative to the WT mice ( $p=0.0041$, Mann-Whitney $U$ test). We quantified the overall $\mathrm{CD}^{+}{ }^{+}$immunoreactivity (Fig $6 C c, g$ ) on the same inflammatory scale used to quantify Ibal and found no significant difference in the two groups at this time point $(p>0.05$; Fig. $6 B b)$. In addition, we quantified the number of CD3immunopositive cells within lesions and found no significant difference between Gas $^{-1-}$ and WT mice (data not shown). Quantification of SMI32 ${ }^{+}$swellings and the representative immunostaining is depicted in Figure $6, B c, C d, C h$. We found that there were significantly more axonal swellings in lumbar spinal cords of $\mathrm{Gas}^{-1-}$ mice relative to WT mice $(p<0.05$, Student's $t$ test). Finally, by MBP immunofluorescent staining and microscopy, we quantified the percentage demyelination in $4 \times$ images (Fig. $6 B d, D$ ). We found $G a s 6^{-I-}$ mice experienced significantly more demyelination than WT mice at this time point during EAE ( $p=0.018$, Student's $t$ test).

Gas6 $^{-1-}$ mice have increased expression of proinflammatory molecules during acute EAE

The significant increase in the number of Iba ${ }^{+}$inflammatory cells in the $\mathrm{Gas}^{-1-}$ mice led us to examine additional mice by qRT-PCR to identify proinflammatory molecules that might contribute to the more severe clinical course in the Gas6 ${ }^{-1-}$ mice. Proinflammatory cytokine and chemokine molecules are expressed in and secreted by multiple CNS cell types, including astrocytes and microglia, as well as infiltrating $\mathrm{T}$ cells and macrophages. Figure $7 A$ shows the clinical course for the 2 cohorts examined specifically for this analysis. RNA was isolated from lumbar spinal cord of mice having clinical scores for $8 \mathrm{~d}$ because we typically found that WT and Gas $6^{-1-}$ scores diverge and become significantly different at this time point. On the day of killing, the average score of the WT mice $(n=8)$ was $1.5 \pm 0.2$ versus $2.5 \pm 0.15$ for the Gas6 $^{-/-}$mice $(n=9)(p=0.002)$. Consistent with the graph showing the combined scores illustrated in Figure 6A, clinical scores in the WT mice began to decline after $\sim 4$ consecutive days, whereas the clinical scores of the Gas6 $^{-1-}$ mice remained elevated.

Proinflammatory cytokines/chemokines and other markers of inflammation were elevated in the two groups of mice. Figure $7 B$ shows there was a significant increase in TNF $\alpha, I L-6, C D 68$, and $I L-17$ in Gas6 $^{-1-}$ spinal cord relative to WT spinal cord. Examination of T-cell-associated cytokines $I L-2, I L-17$, and $I F N \gamma$ showed that the Th17 proinflammatory cytokine $I L-17$ was significantly increased in the Gas6-treated mice $(p=0.02) ; I L-2$ and $I F N \gamma$ were increased $\sim 2$-fold, but significance was not obtained. We found that the chemokines RANTES (CCL5) and MCP-1 (CCL2) were elevated $\sim 2$-fold in the Gas $^{-1-}$ mice, but significance was not obtained. The chemokine CCL3/MIP1 $\alpha$ was significantly increased in the WT spinal cord relative to $G a s 6^{-1-}$, 
A

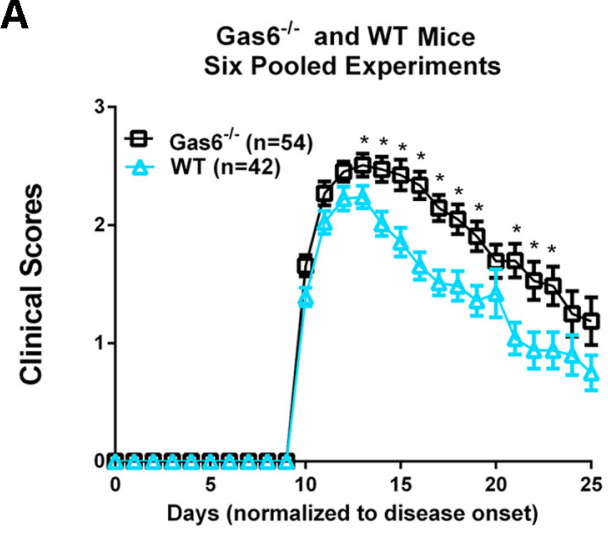

C
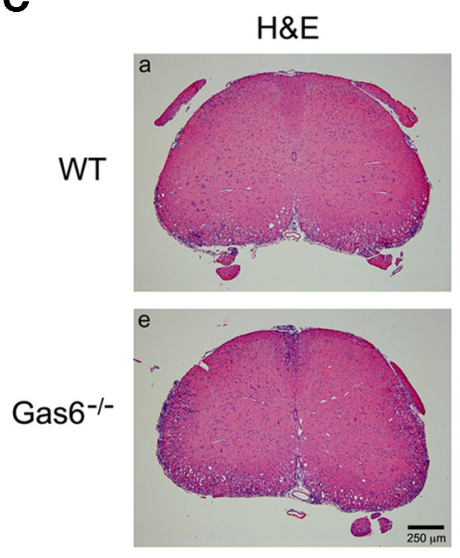

D
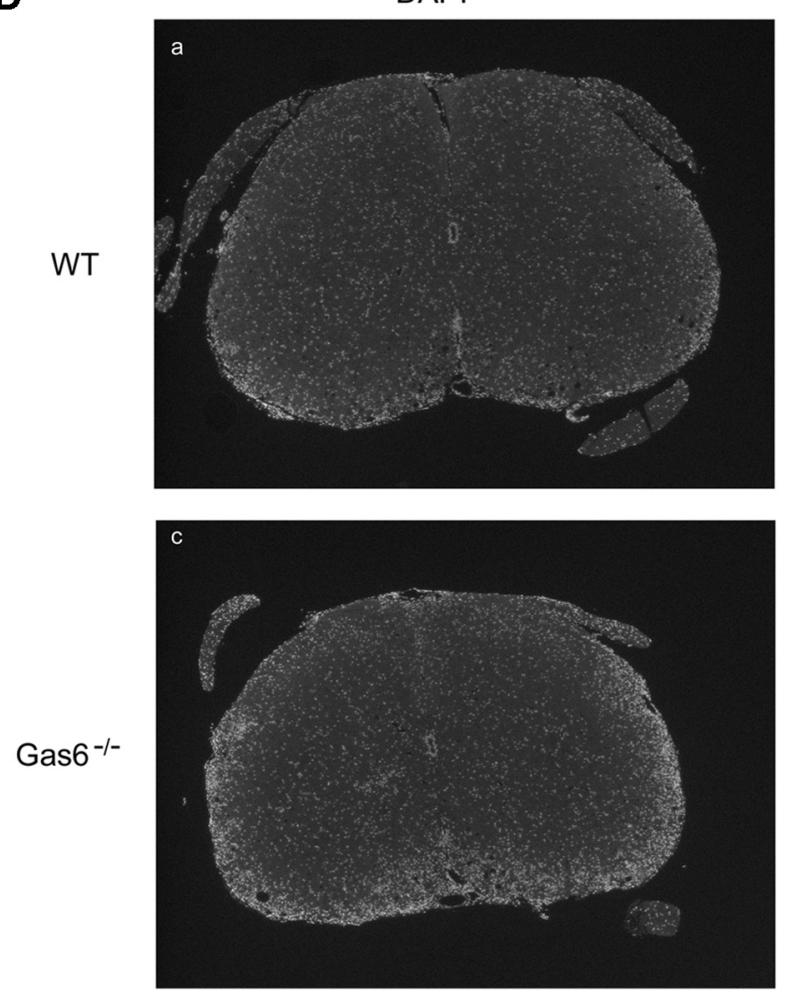

B
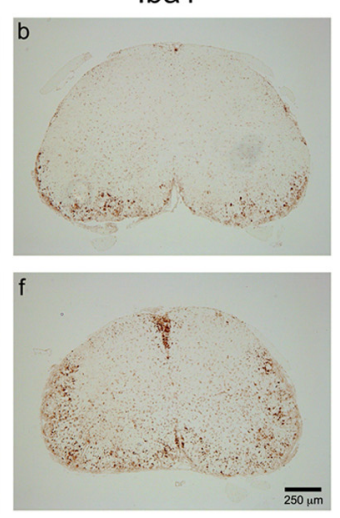
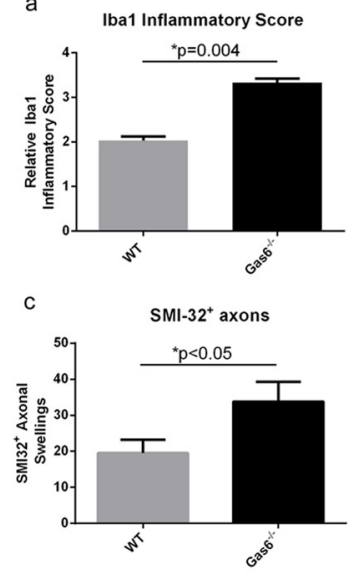

CD3
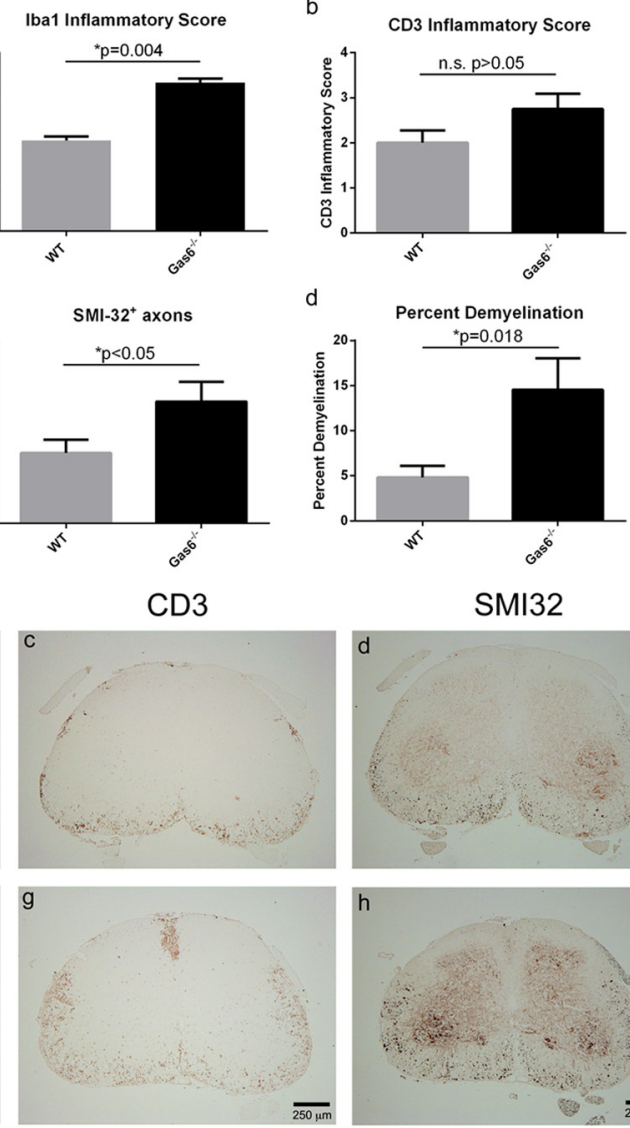

SMI32
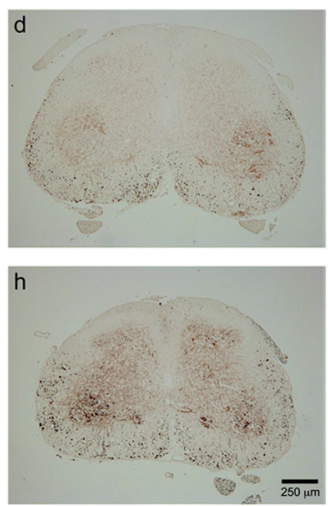

Composite
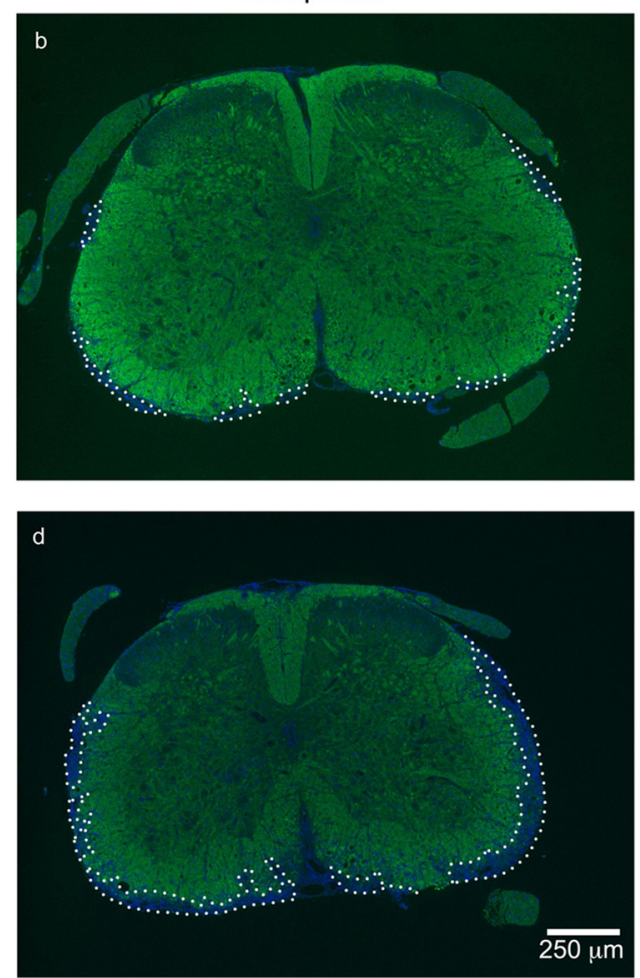

Figure 6. Gas6 $6^{-1-}$ mice have a more severe disease course than WT mice during EAE. A, Six pooled experiments illustrate higher clinical scores during peak acute disease and recovery in Gas $^{-1-}$ mice compared with WT mice. There was no difference in the mean day of disease onset in Gas6 ${ }^{-1-}(n=54)$ and WT $(n=42)$ mice; data were normalized to day 10 , the first day the mice had a clinical score. Significant differences in the composite scores begin at peak disease and continue into the chronic phase. ${ }^{*} p \leq 0.05 . B$, Quantification of immunohistochemical staining in $\mathbf{C}$ and immunofluorescent staining in D. Comparison of $\mathrm{Gas}^{-1-}$ and WT cohorts were analyzed from sensitized mice within the same study. Ba, At day 20 after (Figure legend continues.) 
which was unexpected given that this proinflammatory chemokine is associated with the acute response, where it can induce the synthesis and release of other proinflammatory cytokines including $I L-6, T N F \alpha$, and $I L-1 \beta$.

We examined $I L-4, I L-13, I L-10$, and TGF- $\beta$ expression to determine whether there was differential expression of these cytokines described as anti-inflammatory in the context of EAE. IL-4 is predominantly expressed by a subpopulation of activated Th2 cells and $I L-13$ is expressed by lymphocytes. IL-10 is predominantly synthesized by monocytes, Th2 cells, and $\mathrm{CD} 4{ }^{+} \mathrm{CD} 25^{+} \mathrm{Foxp}^{+}{ }^{+}$regulatory T cells. Although we did not observe a significant change in the expression of these antiinflammatory cytokines in the two groups of mice, we did observe a trend toward less IL-13 mRNA in the Gas $6^{-1-}$ spinal cord. IL-13 is known to inhibit mRNA expression of several cytokines, including $T N F \alpha, M C P-1, I L-1 \beta$, and TGF- $\beta$ (Zhu et al., 2010), which is consistent with our data showing either a trend toward or a significant increase in $T N F \alpha, M C P-1$, and TGF- $\beta$ mRNA in the $\mathrm{Gas}^{-1-}$ group of mice. TGF- $\beta$ was significantly increased in Gas6 $^{-1-}$ spinal cord. TGF- $\beta$ was shown to increase CCL2/MCP1 production and to activate CCR2 to enhance cell motility and alter actin cytoskeletal dynamics (Lee et al., 2009). However, the role of TGF- $\beta$ in EAE is complex, because it was initially described as protective, but more recently was shown to be important in the initiation of EAE primarily through its role in Th17 differentiation (Kuruvilla et al., 1991; Bettelli et al., 2006); our data agree with the latter because we see a significant increase in TGF- $\beta$ and $I L-17$ mRNA. CD68 and CCR2, expressed in microglia/macrophages, were significantly increased in $\mathrm{Gas}^{-/-}$spinal cord, which is consistent with the increased TGF- $\beta$ in Gas6 ${ }^{-1-}$ mice. Expression of the fractalkine receptor $C X C 3 R 1$ was not altered.

Upregulation of suppressor of cytokine signaling-1 (SOCS-1) and SOCS-3 mRNA is induced by several cytokines including IL-6 and IFN $\gamma$. We observed a significant increase in SOCS-3 mRNA in $\mathrm{Gas}^{-1-}$ spinal cord $(p=0.03)$ that correlated with the significant increase in $I L-6 \mathrm{mRNA}$ expression. SOCS-1 was also elevated in $\mathrm{Gas}^{-1-}$ spinal cord, but significance was not achieved.

We addressed whether Pros1 expression might compensate for the loss of Gas6 and investigated whether Axl, Tyro3, and Mertk Mertk might be altered because there is precedence for TGF $\beta 1$ inducing $A x l$ expression (Bauer et al., 2012) and we found $T G F \beta 1$ to be increased in Gas $6^{-1-}$ spinal cord. In addition, Tyro3 expression is increased in the mature CNS, where its expression parallels synaptogenesis, suggesting that Tyro3 expression may be altered in $\mathrm{Gas}^{-1-}$ spinal cord during EAE. Figure $7 B$ shows that

\footnotetext{
(Figure legend continued.) sensitization, there was more extensive Iba1 immunostaining based on our relative lba1+ inflammatory scoring in the lumbar spinal cords of Gas $6^{-1-}$ mice $(3.33 \pm 0.22, p=6)$ relative to WT mice $(2.04 \pm 0.23, p=7)(p=0.004$, Mann-Whitney U). $\mathbf{B} \boldsymbol{b}, \mathrm{CD}^{+}$staining was assessed according to the same parameters discussed for the Iba1 inflammatory scoring system. We found that $\mathrm{CD} 3^{+}$inflammatory score was not significantly increased in Gas6 $6^{-1-}$ spinal cords $2.75 \pm 0.34(n=6)$ different relative to WT spinal cords $2.0 \pm 0.28(n=7)\left(p>0.05\right.$, Mann-Whitney U). BC, The number of SMI $32^{+}$swellings was significantly higher in Gas6 ${ }^{-1-} 33.79 \pm 5.49$ mice relative to WT mice $19.54 \pm 3.72(p<$ 0.05 , Student's $t$ test). $\boldsymbol{B d}$, The percentage demyelination was significantly increased in Gas $^{-1-}$ spinal cords $14.54 \pm 3.51 \%$ relative to WT spinal cords $4.825 \pm 1.28 \%(p=0.018$, Student's $t$ test). C, H\&E (Ca, (e), Iba1 ( $(\boldsymbol{b}, \boldsymbol{C}), \mathrm{CD} 3(\boldsymbol{C c}, \boldsymbol{C g})$, and SMI32 (Cd, Ch) staining of WT and $G a s 6^{-l-}$ representative spinal cord sections. D, IF staining of representative WT $(\boldsymbol{F a}, \boldsymbol{F b})$ and $\mathrm{Gas}^{-1-}(\boldsymbol{F} \boldsymbol{c}, \boldsymbol{F} \boldsymbol{d})$ mice. $\boldsymbol{F a}-\boldsymbol{F d}$, Blue $=\operatorname{DAPI}(\boldsymbol{F} \boldsymbol{b}, \boldsymbol{F} \boldsymbol{d})$; green $=$ MBP $(\boldsymbol{F} \boldsymbol{b}, \boldsymbol{F} \boldsymbol{d})$, a merge/ composite of MBP and DAPI. White dots trace areas of demyelination.
}

there was no change in Pros1, Axl, or Mertk mRNA in spinal cord of the two groups. In contrast, Tyro3 was significantly decreased in Gas $^{-1-}$ spinal cord relative to WT spinal cord $(p<0.05)$. The observed decrease in Tyro3 expression is consistent with the observed axonal damage and reduced MBP immunostaining detected in the $\mathrm{Gas}^{-1-}$ spinal cord.

All three TAM receptors and Gas6 are expressed in white matter during myelination (Prieto et al., 2000; Shankar et al., 2006) and Gas6 has been shown to play important roles in oligodendrocyte survival, maturation, and myelination. This led us to explore whether there were EAE-induced changes in gene expression in two essential oligodendrocyte transcription factors, Olig2 and Sox10, both expressed throughout oligodendrocyte development and maturation, and the early oligodendrocyte receptor PDGFR $\alpha$. The HMG domain transcription factor Sox10 is expressed immediately after oligodendrocyte specification and is known to regulate PDGFR $\alpha$ and MBP expression (Stolt et al., 2002; Finzsch et al., 2008). As depicted in Figure 7, Olig2, Sox10, and PDGFR $\alpha$ were significantly reduced in Gas $^{-1-}$ lumbar spinal cord relative to WT mice $(p<0.05)$, which is consistent with demyelination in Gas $6^{-1-}$ spinal cord mice relative to WT spinal cord (Fig. 6D).

\section{Gas6 $^{-1-}$ mice have significantly more macrophages infiltrating the spinal cord than WT spinal cords during acute EAE}

The significant increase in Iba1+ microglia/macrophages and the increase in inflammatory cytokine gene expression in the Gas $6^{-1-}$ and WT spinal cords during EAE led us to examine the populations of potentially inflammatory immune cells by flow cytometry. We chose to examine the peak of disease (3-4 d sick) because this is when the largest number of immune cells infiltrating the CNS are present. We found a significant, 3.4-fold increase in $\mathrm{CD} 11 \mathrm{~b}^{+} \mathrm{CD} 45 \mathrm{hi} \mathrm{CD}_{68}{ }^{+}$macrophages in $\mathrm{Gas6}^{-1-}$ spinal cord relative to WT. (Fig. $8 A, C ; p=0.0005$, Student's $t$ test). Activated T cells, $\mathrm{CD} 4{ }^{+} \mathrm{CD} 25^{+} \mathrm{CD} 44^{+}$, were marginally increased in $\mathrm{Gas6}^{-1-}$ spinal cord relative to WT spinal cord but were not significantly higher (Fig. $8 B, C$ ); the total number of $\mathrm{CD}^{+}{ }^{+}$cells was also similar between the two cohorts. In addition, we examined the percentages of microglia, B cells, Tregs, and Th17 T cells and found no significant differences in the $\mathrm{Gas}^{-1-}$ and WT spinal cords at this time point. The clinical scores of the Gas $6^{-1-}$ mice were higher the day of killing, but not significantly different between $\mathrm{Gas}^{-1-}(\mathrm{CI}=2.313)$ and WT $(\mathrm{CI}=1.714)$ ( $p=0.065$, Mann-Whitney $U$ test). These results are consistent with our data in Figures 6 and 7.

Our combined data show that loss of Gas6 signaling enhances inflammation, increases axonal damage and demyelination, and impairs recovery during EAE. Targeted Gas6 delivery to the CNS of WT mice during EAE reduces the clinical course of EAE, Iba1 macrophage/microglia expression, and SMI32 axonal swelling and demyelination.

\section{Discussion}

Because a preponderance of studies show an important role for GAS6 in the regulation of inflammation and because our own in vitro and in vivo studies showed that GAS6 enhanced oligodendrocyte survival and myelination (Shankar et al., 2003; Shankar et al., 2006; Tsiperson et al., 2010; O'Guin et al., 2014), we tested the hypothesis that GAS6 would be beneficial in an autoinflammatory model of multiple sclerosis, EAE. In the context of the EAE inflammatory environment, we posited that GAS6/TAM signaling is influential in regulating inflammatory gene expression and maintaining axonal integrity and myelination in the CNS. 
A

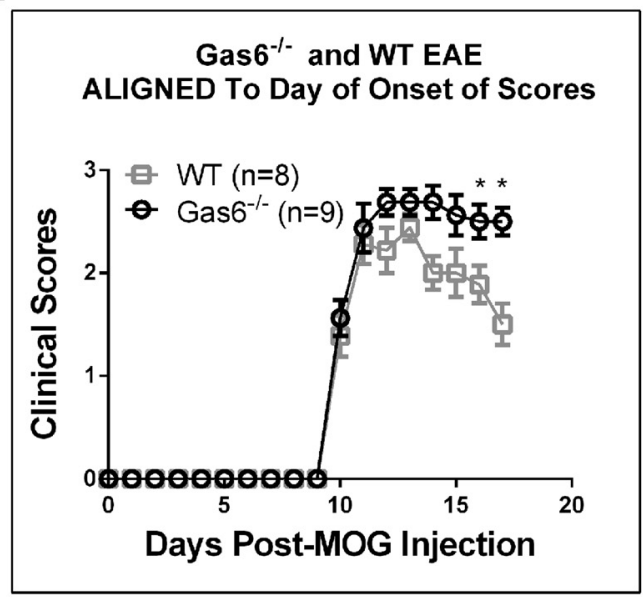

Inflammatory Chemokines

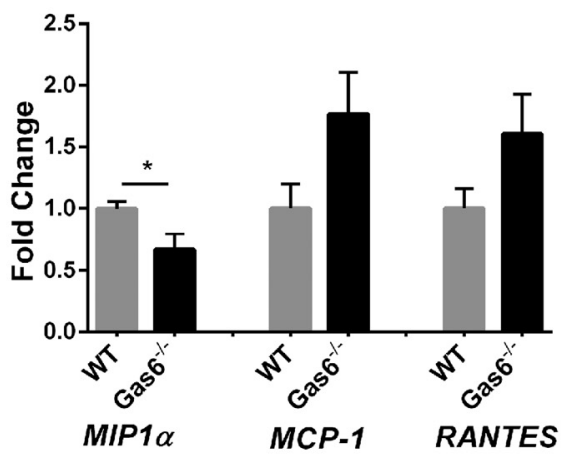

Anti-Inflammatory Cytokines

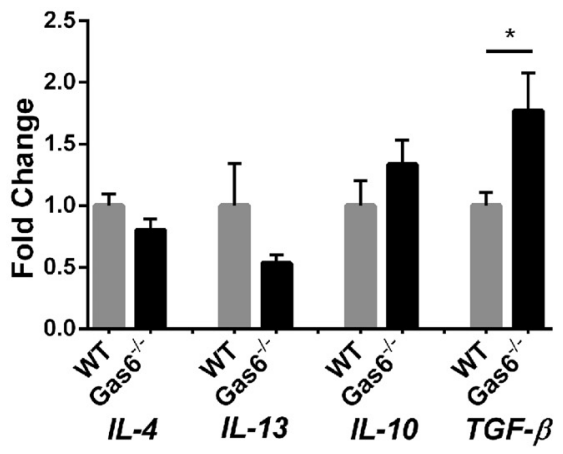

TAM Signaling

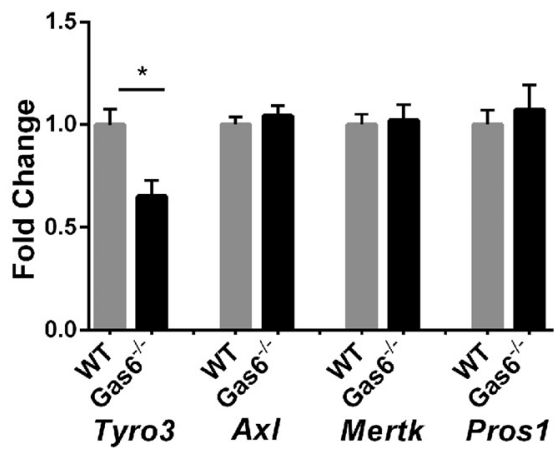

B
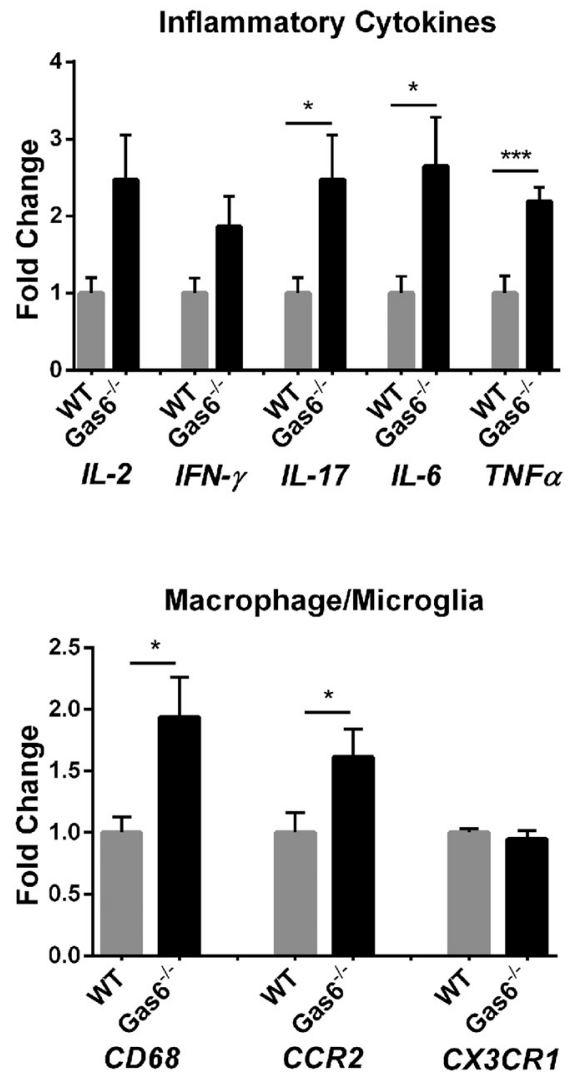

socs 1,3

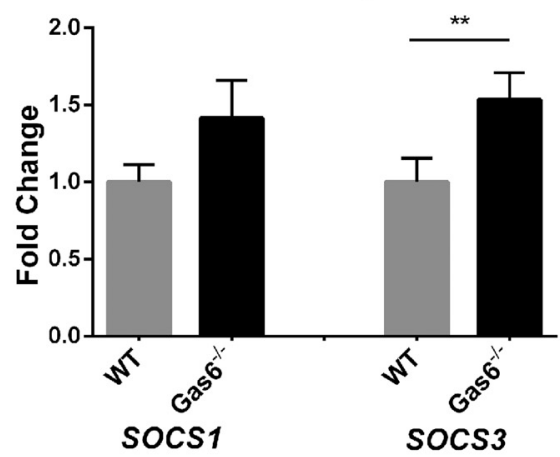

Oligodendrocyte Lineage

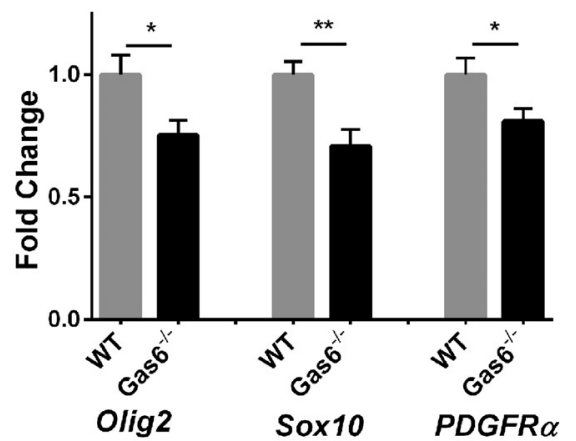

Figure 7. qRT-PCR demonstrates that, relative to WT mice, Gas $6^{-1-}$ mice have increased cytokine/chemokine mRNA expression in spinal cord and reduced expression of oligodendrocyte markers during EAE. A, Clinical course of Gas $6^{-1-}$ and WT mice sensitized with $\mathrm{MOG}_{35-55}$ peptide. All mice with scores $\geq 1.0$ were killed after having scores for $8 \mathrm{~d}$. On the day of killing, the average score of the WT mice $(n=8)$ was $1.5 \pm 0.2$ versus $2.5 \pm 0.15$ for the Gas $6^{-l-}$ mice $(n=9)(p=0.002)$. B, qRT-PCR shows that Gas ${ }^{-l-}$ mice have increased inflammatory cytokine expression and decreased expression of oligodendrocyte lineage markers. ${ }^{*} p \leq 0.05 ;{ }^{* *} p \leq 0.01 ;{ }^{* * *} p \leq 0.001$. 
A

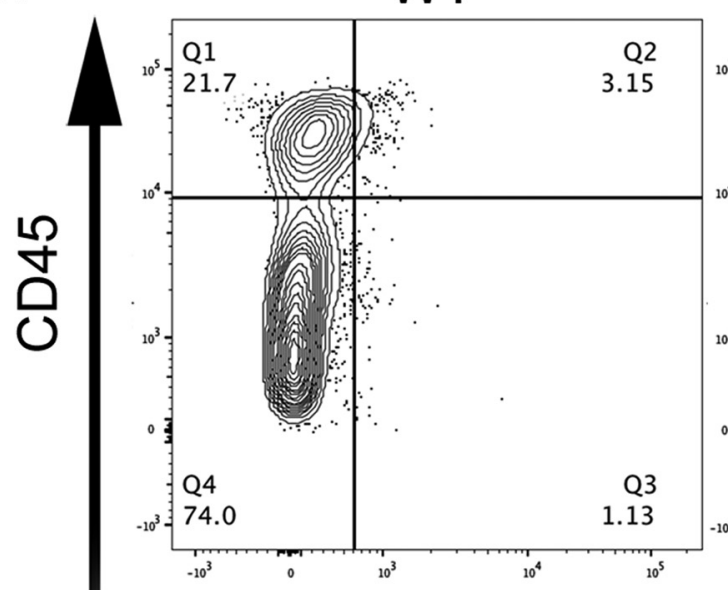

Gas $6^{-/-}$

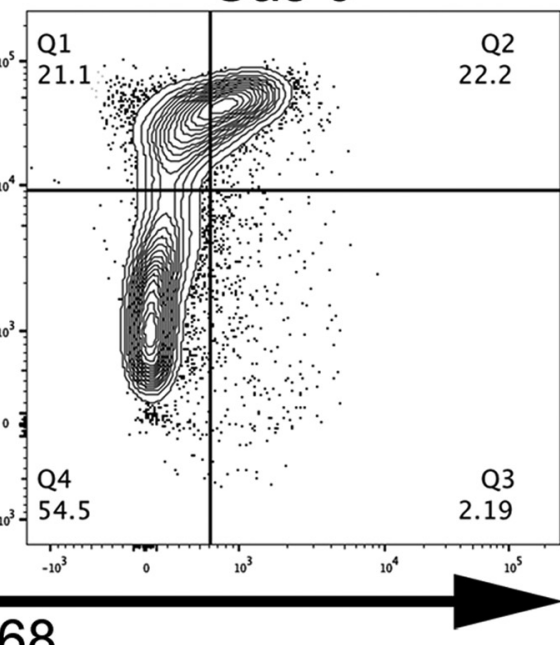

\section{CD68}

B

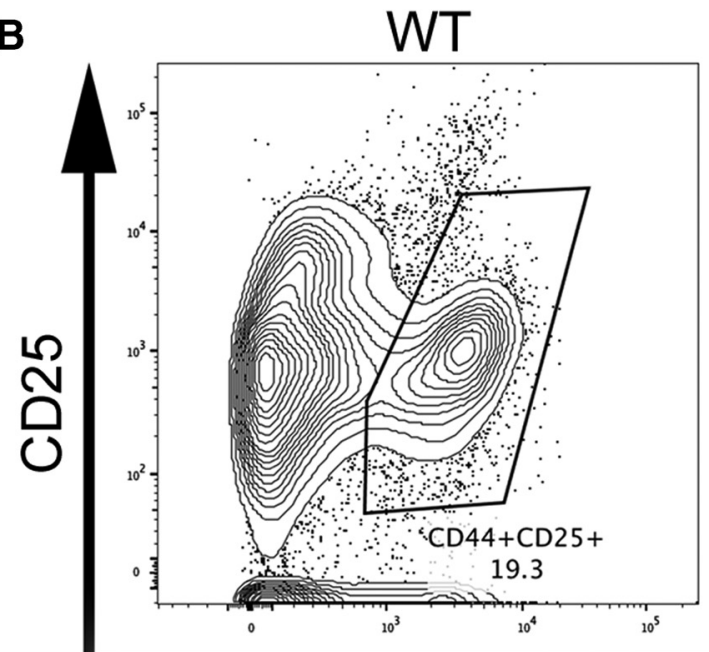

Gas $6^{-/-}$

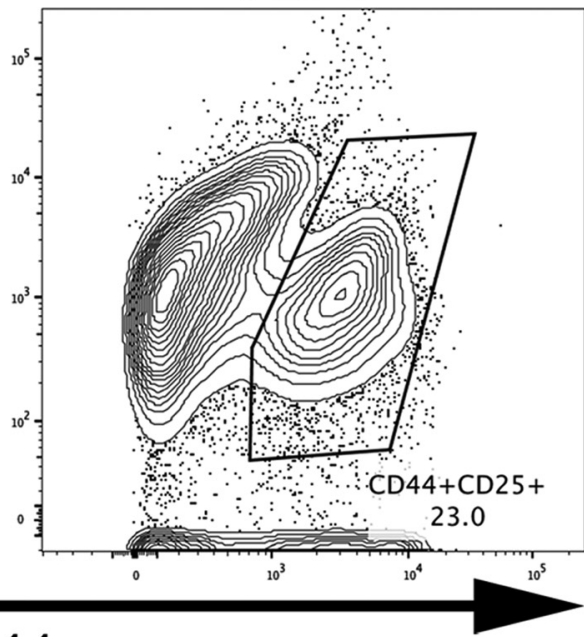

CD44

C
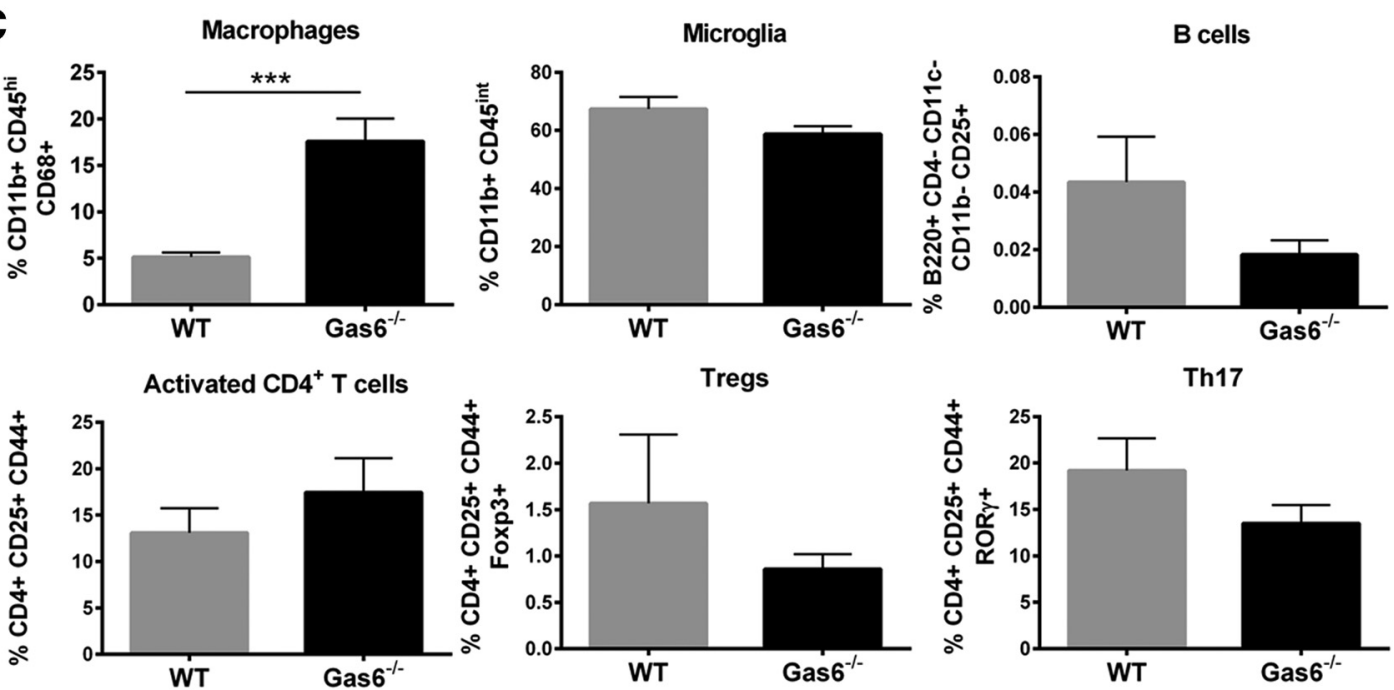

Figure 8. Flow cytometry analysis demonstrates an increase in $\mathrm{CD} 11 \mathrm{~b}{ }^{+} \mathrm{CD} 45 \mathrm{hiC} 688^{+}$macrophages in Gas6 ${ }^{-1-}$ spinal cord/mice during EAE. $A, C$, Macrophages $\left(\mathrm{CD} 11 \mathrm{~b}{ }^{+} \mathrm{CD} 688^{+} \mathrm{CD} 45 \mathrm{hi}\right.$ $\mathrm{CD} 4^{-} \mathrm{B} 220^{-}$), expressed as the percentage of single cells $\mathrm{CD} 11 \mathrm{~b}^{+} \mathrm{CD}^{-} \mathrm{B} 22 \mathrm{O}^{-}$, were assessed by flow cytometry in cells isolated from the spinal cord of Gas $6^{-1-}$ and WT mice during acute EAE, mice had scores for $3-4 \mathrm{~d}$. WT mice had $5.1 \pm 0.5 \%$ macrophages in the spinal cord, whereas Gas $6^{-1-}$ mice displayed a significantly higher percentage of macrophages (Figure legend continues.) 
We report that, in WT spinal cords, Mertk expression was significantly increased in mice with clinical scores for 4 and 8 days, corresponding to acute disease, a period when activated inflammatory cells infiltrate the CNS and contribute to glial activation. Gas 6 and $A x l$ mRNA expression were both significantly increased at day 8 and $A x l$ was elevated throughout the EAE course. Pros 1 and Tyro3 mRNA expression were not significantly altered in WT spinal cords during EAE.

Our study demonstrates that continual intracerebroventricular GAS6 delivery by micro-osmotic pump was beneficial. Relative to the ACSF-treated mice, clinical scores were reduced during peak acute and chronic disease. Although a significant difference in Ibal ${ }^{+}$staining was not observed during the chronic phase of EAE after GAS6 treatment, we did observe significantly fewer SMI $32^{+}$axonal swellings and spheroids and more robust SMI $31^{+}$axons in the spinal cord of GAS6-treated mice relative to the ACSF-treated mice, indicative of reduced axonal damage. Further, more robust $\mathrm{MBP}^{+}$immunoreactivity, an indicator of myelination, was observed in the spinal cord of GAS6-treated mice consistent with healthier $\mathrm{SMI} 31^{+} \mathrm{SMI} 32^{-}$axons and protected myelin ensheathment. GAS6-mediated axonal protection is likely the result of both its anti-inflammatory properties and its known role as a neurotrophic factor (Allen et al., 1999; Prieto et al., 2000; Funakoshi et al., 2002; Yagami et al., 2002; Gely-Pernot et al., 2012).

Although the mechanism of IFN $\beta$ action is not well defined, IFN $\beta$ is administered to individuals with MS to reduce relapses. IFN $\alpha$ and IFN $\beta$ signal through IFNR1/2 to maintain homeostasis and to reduce inflammation. TLR activation of IFNR $1 / 2$ by IFN $\alpha$ increases TAM signaling resulting in AXL binding to IFNR1/2 and reduced inflammation (Rothlin et al., 2007). IFN $\beta$ exerts positive feedback over the induction of IFN $\alpha$ genes (Marié et al., 1998). When we compared GAS6 treatment alone with GAS6 + IFN $\beta$, we determined that GAS6 was more potent and GAS6 + IFN $\beta$ did not result in a synergistic response nor significantly reduce axonal dystrophy; no further IFN $\beta$ studies were pursued. It is possible that the simultaneous addition of GAS6 + IFN $\beta$ altered availability and homoeostasis of the TAM receptors with fewer membrane-bound TAMs available for inhibiting the inflammatory response. This analysis is beyond the scope of the current study and will require further extensive evaluation.

To further corroborate the importance of GAS6 in maintaining the integrity of the CNS, we show that $\mathrm{Gas}^{-1-}$ mice were more severely compromised during EAE. Unlike the triple Tyro3/ Axl/Mertk knock-out mice (Lu and Lemke, 2001), naive Gas6 ${ }^{-1-}$ mice are not severely immunocompromised. However, during EAE, Gas $6^{-1-}$ mice had a more severe peak and chronic phase of disease, with delayed recovery, increased $\mathrm{Iba}^{+}$glia, increased expression of proinflammatory molecules, decreased expression

\footnotetext{
(Figure legend continued.) $17.6 \pm 2.5 \%$ ( $p=0.0005$, Student's $t$ test). B, C, Activated T cells $\left(\mathrm{CD} 4{ }^{+} \mathrm{CD} 44^{+} \mathrm{CD}^{+} 5^{+}\right)$are expressed as a percentage of total $\mathrm{CD} 4{ }^{+}$. Activated T cells were not significantly higher in Gas6 ${ }^{-1-}$ spinal cord/mice $17.5 \pm 3.7 \%$ compared with WT spinal cord $13.1 \pm 2.6 \%$ ( $p>0.05$, Student's $t$ test). C, Quantification of the percentages of populations of infiltrating and resident immune cells in the CNS of $\mathrm{Gas}^{-1-}$ and WT mice. Microglia are expressed as percentage of $\mathrm{CD} 11 \mathrm{~b}^{+} \mathrm{CD}^{-}{ }^{-} \mathrm{B} 220^{-}$single cells identified as $\mathrm{CD} 45$ intermediate. $B$ cells are expressed as the percentage of single cells defined as $\mathrm{CD} 45 \mathrm{R} / \mathrm{B} 220^{+} \mathrm{CD} 25^{+} \mathrm{CD} 4^{-}$

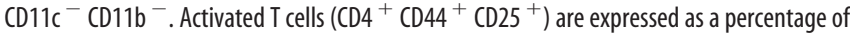
total $\mathrm{CD} 4{ }^{+}$single cells. Th17 and Tregs are expressed as the percentage of activated T cells that are ROR $\gamma \mathrm{t}^{+}$and Foxp $3^{+}$, respectively. With the exception of macrophages, the $p$-value for all of the examined populations was $p>0.05$.
}

of oligodendrocyte markers, and increased numbers of axonal swellings.

Relative to WT mice, we observed significantly higher $C D 68$, $I L-17, I L-6, T N F \alpha$, and SOCS3 and less MIP-1 $\alpha$ (CCL3) mRNA expression in lumbar spinal cord of $\mathrm{Gas}^{-1-}$ mice having clinical scores for $8 \mathrm{~d}$. CD68 is expressed on the cell surface of monocytes, macrophages, and microglia and its increased mRNA expression is consistent with the increase in relative amount of $\mathrm{Ibal}^{+} \mathrm{im}^{-}$ munostaining in the Gas $^{-1-}$ spinal cords. Using flow cytometry analysis, we determined that there was a significant increase in $\mathrm{CD}_{11 \mathrm{~b}}{ }^{+} \mathrm{CD} 45^{\mathrm{hi}} \mathrm{CD} 8^{+}$macrophages during acute EAE in Gas6 $^{-/-}$spinal cords, which corroborates the increase in Ibal ${ }^{+}$ cells that we observed in tissue sections. Furthermore, we did not find significant differences in activated T-cells, Tregs, Th17 cells, B cells, or microglia between WT and $\mathrm{Gas}^{-1-}$ mice at 3-4 d sick.

Th17 cells infiltrate the brain before the development of clinical symptoms of EAE, resulting in activated microglia and increased IL-17, TNF $\alpha$, IL- 6 , and IL- $1 \beta$ proinflammatory cytokine production and increased CNS inflammation (Murphy et al., 2010). Several proinflammatory cytokines, including IL-6, $\mathrm{TNF} \alpha$, and MIP- $1 \alpha$, are expressed in the CNS and are secreted by microglia and/or astrocytes as well as macrophages. IL-6 activation can activate Janus kinases (JAKs)/ STAT/MAPK pathways, and alter gene expression (Taga and Kishimoto, 1997; Van Wagoner et al., 1999), whereas IL-6 can suppress TNF $\alpha$, which itself can promote inflammation or remyelination depending upon which receptor (TNFR1 or TNFR2) is activated (Arnett et al., 2001). Gas6 $6^{-1-}$ mice have significantly increased amounts of both $I L-6$ and $T N F \alpha$ mRNA in lumbar spinal cords relative to sensitized WT spinal cords, indicating that these cytokines contribute to the increased CNS injury and higher clinical scores seen in Gas6-deficient mice.

Signaling from Gas6 to TAM receptors dampens inflammation, reduces expression, and enhances phagocytosis in macrophages/microglia (Grommes et al., 2008; Alciato et al., 2010). M2 noninflammatory macrophages are associated with improvement of neurological impairment during EAE (Denney et al., 2012). M2c macrophages express MERTK and GAS6 in a positive feedback loop that promotes debris clearance and reduces inflammation; IL-4, IL-10, and glucocorticoids increase Gas6 production (Zizzo et al., 2012). In addition, astrocytes were shown to mediate synapse elimination by signaling through the MERTK and MEGF10 pathways, demonstrating a role for MERTK and PROS1 in phagocytic synapse remodeling (Chung et al., 2013). In our EAE model, Pros1 was not transcriptionally upregulated in the CNS, but PROS1 signaling cannot be ruled out. However, we previously demonstrated that deletion of $A x l$ results in increased myelin debris and reduced myelination during cuprizone intoxication and EAE. This is consistent with other TAM members in addition to MERTK/PROS1 participating in debris clearance and repair (Seitz et al., 2007; Hoehn et al., 2008; Weinger et al., 2011; Zagórska et al., 2014).

We report a significant reduction in Olig2, Sox10, and PDGFR $\alpha$ expression in Gas $^{-/-}$spinal cord relative to WT spinal cord that is consistent with studies showing that GAS6 functions in oligodendrocyte survival and maturation (Shankar et al., 2003; Shankar et al., 2006; Binder et al., 2008; Tsiperson et al., 2010; Binder et al., 2011; O'Guin et al., 2014). Olig2 is important for the differentiation of neural progenitor cells into the oligodendrocyte lineage (Copray et al., 2006; Ligon et al., 2006) because Olig2 disruption results in a lack of $\mathrm{NG}_{2}{ }^{+} \mathrm{OPCs}$ and in decreased numbers of oligodendrocytes in the spinal cord (Lu et al., 2002; Ligon et al., 2006). Sox10 promotes terminal oligodendrocyte 
differentiation and deletion of Sox10 disrupts oligodendrocyte differentiation (Stolt et al., 2002). Further, Sox10 influences survival and migration of oligodendrocyte precursors in the spinal cord by regulating PDGFR $\alpha$ and MBP expression (Finzsch et al., 2008). TYRO3 expression increases in the CNS during postnatal development (Prieto et al., 2000) and Tyro3 mRNA transcripts increase as oligodendrocytes mature (Cahoy et al., 2008). We found that Tyro3 transcripts were significantly reduced in spinal cord of $\mathrm{Gas}^{-1-}$ mice with scores for 8 consecutive days, suggesting that diminished axonal integrity and remyelination in the damaged CNS results in reduced Tyro3 mRNA expression. Although our data support the hypothesis that GAS6 signaling is an important mediator of protective effects in the CNS during EAE, future studies creating GAS6/receptor double knock-out mice will address the relative contributions of each receptor to CNS protection and elucidate to what degree PROS1 and other TAM receptors are compensating.

Our data provide compelling support for a beneficial effect of GAS6 during an inflammatory model of MS, EAE. There is building evidence that GAS6/TAM signaling is altered in human disease, including MS (Weinger et al., 2009; Sainaghi et al., 2013) and other autoimmune diseases such as rheumatoid arthritis, inflammatory bowel disease, and lupus (Bassyouni et al., 2014; Rothlin et al., 2014; Zhu et al., 2014). In addition, MERTK, located on human chromosome $2 \mathrm{q} 14.1$, has been identified as a gene associated with a possible genetic risk factor for MS (Sawcer and Hellenthal, 2011; Raj et al., 2014). Seven MERTK SNPs ( $p<$ 0.05 ) were suggestive of an association with MS (Ma et al., 2011), further implicating a role for TAM receptors in autoimmune disease and specifically MS.

Currently approved treatments for multiple sclerosis are focused on disruption of the inflammatory component of the disease; however, GAS6 has the ability to influence other aspects of the disease pathogenesis as well. We demonstrate that GAS6 signaling not only dampens inflammation and proinflammatory gene expression, but also influences OPC maturation, enhances myelination, and preserves axonal integrity, functions that IFN $\beta$ cannot achieve. Although an Ommaya reservoir could be used for intracerebroventricular delivery of GAS6, it is likely not an ideal option for clinical treatment of demyelinating disease. However, because GAS6 is a soluble ligand for the TAM receptors, synthetic small-molecule or biologic agonists for these receptors may be an attractive candidate for anti-inflammatory, neuroprotective, and promyelinating therapies.

\section{References}

Alciato F, Sainaghi PP, Sola D, Castello L, Avanzi GC (2010) TNF-alpha, IL-6, and IL-1 expression is inhibited by GAS6 in monocytes/macrophages. J Leukoc Biol 87:869-875. CrossRef Medline

Allen MP, Zeng C, Schneider K, Xiong X, Meintzer MK, Bellosta P, Basilico C, Varnum B, Heidenreich KA, Wierman ME (1999) Growth arrestspecific gene 6 (Gas6)/adhesion related kinase (Ark) signaling promotes gonadotropin-releasing hormone neuronal survival via extracellular signal-regulated kinase (ERK) and Akt. Mol Endocrinol 13:191-201. CrossRef Medline

Arnett HA, Mason J, Marino M, Suzuki K, Matsushima GK, Ting JP (2001) TNF alpha promotes proliferation of oligodendrocyte progenitors and remyelination. Nat Neurosci 4:1116-1122. CrossRef Medline

Bassyouni IH, El-Wakd MM, Azab NA, Bassyouni RH (2014) Diminished soluble levels of growth arrest specific protein 6 and tyrosine kinase receptor Axl in patients with rheumatoid arthritis. Int J Rheum Dis. In press.

Bauer T, Zagórska A, Jurkin J, Yasmin N, Köffel R, Richter S, Gesslbauer B, Lemke G, Strobl H (2012) Identification of Axl as a downstream effector of TGF-betal during Langerhans cell differentiation and epidermal homeostasis. J Exp Med 209:2033-2047. CrossRef Medline
Bettelli E, Baeten D, Jäger A, Sobel RA, Kuchroo VK (2006) Myelin oligodendrocyte glycoprotein-specific $\mathrm{T}$ and $\mathrm{B}$ cells cooperate to induce a Devic-like disease in mice. J Clin Invest 116:2393-2402. CrossRef Medline

Binder MD, Cate HS, Prieto AL, Kemper D, Butzkueven H, Gresle MM, Cipriani T, Jokubaitis VG, Carmeliet P, Kilpatrick TJ (2008) Gas6 deficiency increases oligodendrocyte loss and microglial activation in response to cuprizone-induced demyelination. J Neurosci 28:5195-5206. CrossRef Medline

Binder MD, Xiao J, Kemper D, Ma GZ, Murray SS, Kilpatrick TJ (2011) Gas6 increases myelination by oligodendrocytes and its deficiency delays recovery following cuprizone-induced demyelination. PLoS One 6:e17727. CrossRef Medline

Cahoy JD, Emery B, Kaushal A, Foo LC, Zamanian JL, Christopherson KS, Xing Y, Lubischer JL, Krieg PA, Krupenko SA, Thompson WJ, Barres BA (2008) A transcriptome database for astrocytes, neurons, and oligodendrocytes: a new resource for understanding brain development and function. J Neurosci 28:264-278. CrossRef Medline

Chung WS, Clarke LE, Wang GX, Stafford BK, Sher A, Chakraborty C, Joung J, Foo LC, Thompson A, Chen C, Smith SJ, Barres BA (2013) Astrocytes mediate synapse elimination through MEGF10 and MERTK pathways. Nature 504:394-400. CrossRef Medline

Copray S, Balasubramaniyan V, Levenga J, de Bruijn J, Liem R, Boddeke E (2006) Olig2 overexpression induces the in vitro differentiation of neural stem cells into mature oligodendrocytes. Stem Cells 24:1001-1010. CrossRef Medline

Denney L, Kok WL, Cole SL, Sanderson S, McMichael AJ, Ho LP (2012) Activation of invariant NKT cells in early phase of experimental autoimmune encephalomyelitis results in differentiation of Ly6Chi inflammatory monocyte to M2 macrophages and improved outcome. J Immunol 189:551-557. CrossRef Medline

Finzsch M, Stolt CC, Lommes P, Wegner M (2008) Sox9 and Sox10 influence survival and migration of oligodendrocyte precursors in the spinal cord by regulating PDGF receptor alpha expression. Development 135: 637-646. CrossRef Medline

Funakoshi H, Yonemasu T, Nakano T, Matumoto K, Nakamura T (2002) Identification of Gas6, a putative ligand for Sky and Axl receptor tyrosine kinases, as a novel neurotrophic factor for hippocampal neurons. J Neurosci Res 68:150-160. CrossRef Medline

Gely-Pernot A, Coronas V, Harnois T, Prestoz L, Mandairon N, Didier A, Berjeaud JM, Monvoisin A, Bourmeyster N, De Frutos PG, Philippe M, Benzakour O (2012) An endogenous vitamin K-dependent mechanism regulates cell proliferation in the brain subventricular stem cell niche. Stem Cells 30:719-731. CrossRef Medline

Grommes C, Lee CY, Wilkinson BL, Jiang Q, Koenigsknecht-Talboo JL, Varnum B, Landreth GE (2008) Regulation of microglial phagocytosis and inflammatory gene expression by Gas6 acting on the Axl/Mer family of tyrosine kinases. J Neuroimmune Pharmacol 3:130-140. CrossRef Medline

Hoehn HJ, Kress Y, Sohn A, Brosnan CF, Bourdon S, Shafit-Zagardo B (2008) Axl-/- mice have delayed recovery and prolonged axonal damage following cuprizone toxicity. Brain Res 1240:1-11. CrossRef Medline

Kuruvilla AP, Shah R, Hochwald GM, Liggitt HD, Palladino MA, Thorbecke GJ (1991) Protective effect of transforming growth factor beta 1 on experimental autoimmune diseases in mice. Proc Natl Acad Sci U S A 88: 2918-2921. CrossRef Medline

Lee EY, Chung CH, Khoury CC, Yeo TK, Pyagay PE, Wang A, Chen S (2009) The monocyte chemoattractant protein-1/CCR2 loop, inducible by TGFbeta, increases podocyte motility and albumin permeability. Am J Physiol Renal Physiol 297:F85-94. CrossRef Medline

Ligon KL, Fancy SP, Franklin RJ, Rowitch DH (2006) Olig gene function in CNS development and disease. Glia 54:1-10. CrossRef Medline

Livak KJ, Schmittgen TD (2001) Analysis of relative gene expression data using real-time quantitative PCR and the 2(-Delta Delta C(T)) method. Methods 25:402-408. CrossRef Medline

Lu Q, Lemke G (2001) Homeostatic regulation of the immune system by receptor tyrosine kinases of the Tyro 3 family. Science 293:306-311. CrossRef Medline

Lu QR, Sun T, Zhu Z, Ma N, Garcia M, Stiles CD, Rowitch DH (2002) Common developmental requirement for Olig function indicates a motor neuron/oligodendrocyte connection. Cell 109:75-86. CrossRef Medline

Ma GZ1, Stankovich J; Australia and New Zealand Multiple Sclerosis Genetics Consortium (ANZgene), Kilpatrick TJ, Binder MD, Field J (2011) Polymorphisms in the receptor tyrosine kinase MERTK gene are associated 
with multiple sclerosis susceptibility. PLoS One 6:e16964. CrossRef Medline

Marié I, Durbin JE, Levy DE (1998) Differential viral induction of distinct interferon-alpha genes by positive feedback through interferon regulatory factor-7. EMBO J 17:6660-6669. CrossRef Medline

Murphy AC, Lalor SJ, Lynch MA, Mills KH (2010) Infiltration of Th1 and Th17 cells and activation of microglia in the CNS during the course of experimental autoimmune encephalomyelitis. Brain Behav Immun 24: 641-651. CrossRef Medline

Nagata K, Ohashi K, Nakano T, Arita H, Zong C, Hanafusa H, Mizuno K (1996) Identification of the product of growth arrest-specific gene 6 as a common ligand for Axl, Sky, and Mer receptor tyrosine kinases. J Biol Chem 271:30022-30027. CrossRef Medline

O'Guin KN, Gruber RC, Raine CS, Guzik HM, Poulos BK, Shafit-Zagardo B (2014) Gas6 enhances axonal ensheathment by MBP + membranous processes in human DRG/OL promyelinating co-cultures. ASN Neuro 6:e00135. CrossRef Medline

Prasad D, Rothlin CV, Burrola P, Burstyn-Cohen T, Lu Q, Garcia de Frutos P, Lemke G (2006) TAM receptor function in the retinal pigment epithelium. Mol Cell Neurosci 33:96-108. CrossRef Medline

Prieto AL, Weber JL, Tracy S, Heeb MJ, Lai C (1999) Gas6, a ligand for the receptor protein-tyrosine kinase Tyro-3, is widely expressed in the central nervous system. Brain Res 816:646-661. CrossRef Medline

Prieto AL, Weber JL, Lai C (2000) Expression of the receptor proteintyrosine kinases Tyro-3, Axl, and mer in the developing rat central nervous system. J Compar Neurol 425:295-314. CrossRef Medline

Raj T1, Rothamel K, Mostafavi S, Ye C, Lee MN, Replogle JM, Feng T, Lee M, Asinovski N, Frohlich I, Imboywa S, Von Korff A, Okada Y, Patsopoulos NA, Davis S, McCabe C, Paik HI, Srivastava GP, Raychaudhuri S, Hafler DA, Koller D, Regev A, Hacohen N, Mathis D, Benoist C, Stranger BE, De Jager PL (2014) Polarization of the effects of autoimmune and neurodegenerative risk alleles in leukocytes. Science 344:519-523. CrossRef Medline

Rothlin CV, Lemke G (2010) TAM receptor signaling and autoimmune disease. Curr Opin Immunol 22:740-746. CrossRef Medline

Rothlin CV, Ghosh S, Zuniga EI, Oldstone MB, Lemke G (2007) TAM receptors are pleiotropic inhibitors of the innate immune response. Cell 131:1124-1136. CrossRef Medline

Rothlin CV, Leighton JA, Ghosh S (2014) Tyro3, Axl, and Mertk receptor signaling in inflammatory bowel disease and colitis-associated cancer. Inflamm Bowel Dis 20:1472-1480. CrossRef Medline

Sainaghi PP, Collimedaglia L, Alciato F, Molinari R, Sola D, Ranza E, Naldi P, Monaco F, Leone M, Pirisi M, Avanzi GC (2013) Growth arrest specific gene 6 protein concentration in cerebrospinal fluid correlates with relapse severity in multiple sclerosis. Mediators Inflamm 2013:406483. CrossRef Medline

Sasaki T, Knyazev PG, Clout NJ, Cheburkin Y, Göhring W, Ullrich A, Timpl R, Hohenester E (2006) Structural basis for Gas6-Axl signalling. EMBO J 25:80-87. CrossRef Medline

Sather S, Kenyon KD, Lefkowitz JB, Liang X, Varnum BC, Henson PM, Graham DK (2007) A soluble form of the Mer receptor tyrosine kinase inhibits macrophage clearance of apoptotic cells and platelet aggregation. Blood 109:1026-1033. CrossRef Medline

Sawcer S, Hellenthal G (2011) The major histocompatibility complex and multiple sclerosis: a smoking gun? Brain 134:638-640. CrossRef Medline

Seitz HM, Camenisch TD, Lemke G, Earp HS, Matsushima GK (2007) Macrophages and dendritic cells use different Axl/Mertk/Tyro3 receptors in clearance of apoptotic cells. J Immunol 178:5635-5642. CrossRef Medline

Shankar SL, O'Guin K, Cammer M, McMorris FA, Stitt TN, Basch RS, Varnum B, Shafit-Zagardo B (2003) The growth arrest-specific gene product Gas6 promotes the survival of human oligodendrocytes via a phosphatidylinositol 3-kinase-dependent pathway. J Neurosci 23:42084218. Medline

Shankar SL, O’Guin K, Kim M, Varnum B, Lemke G, Brosnan CF, Shafit-
Zagardo B (2006) Gas6/Axl signaling activates the phosphatidylinositol 3-kinase/Akt1 survival pathway to protect oligodendrocytes from tumor necrosis factor alpha-induced apoptosis. J Neurosci 26:5638-5648. CrossRef Medline

Soulika AM, Lee E, McCauley E, Miers L, Bannerman P, Pleasure D (2009) Initiation and progression of axonopathy in experimental autoimmune encephalomyelitis. J Neurosci 29:14965-14979. CrossRef Medline

Stitt TN, Conn G, Gore M, Lai C, Bruno J, Radziejewski C, et al. (1995) The anticoagulation factor protein $\mathrm{S}$ and its relative, Gas6, are ligands for the Tyro 3/Axl family of receptor tyrosine kinases. Cell 80:661-670. CrossRef Medline

Stolt CC, Rehberg S, Ader M, Lommes P, Riethmacher D, Schachner M, Bartsch U, Wegner M (2002) Terminal differentiation of myelinforming oligodendrocytes depends on the transcription factor Sox10. Genes Dev 16:165-170. CrossRef Medline

Taga T, Kishimoto T (1997) Gp130 and the interleukin-6 family of cytokines. Annu Rev Immunol 15:797-819. CrossRef Medline

Tsiperson V, Li X, Schwartz GJ, Raine CS, Shafit-Zagardo B (2010) GAS6 enhances repair following cuprizone-induced demyelination. PLoS One 5:e15748. CrossRef Medline

Tsiperson V, Gruber RC, Goldberg MF, Jordan A, Weinger JG, Macian F, Shafit-Zagardo B (2013) Suppression of inflammatory responses during myelin oligodendrocyte glycoprotein-induced experimental autoimmune encephalomyelitis is regulated by AKT3 signaling. J Immunol 190: 1528-1539. CrossRef Medline

Tsou WI, Nguyen KQ, Calarese DA, Garforth SJ, Antes AL, Smirnov SV, Almo SC, Birge RB, Kotenko SV (2014) Receptor tyrosine kinases, TYRO3, AXL, and MER, demonstrate distinct patterns and complex regulation of ligand-induced activation. J Biol Chem 289:25750-25763. CrossRef Medline

Van Wagoner NJ, Oh JW, Repovic P, Benveniste EN (1999) Interleukin-6 (IL-6) production by astrocytes: autocrine regulation by IL-6 and the soluble IL-6 receptor. J Neurosci 19:5236-5244. Medline

Varnum BC, Young C, Elliott G, Garcia A, Bartley TD, Fridell YW, Hunt RW, Trail G, Clogston C, Toso RJ, et al. (1995) Axl receptor tyrosine kinase stimulated by the vitamin K-dependent protein encoded by growtharrest-specific gene 6. Nature 373:623-626. CrossRef Medline

Weinger JG, Omari KM, Marsden K, Raine CS, Shafit-Zagardo B (2009) Up-regulation of soluble Axl and Mer receptor tyrosine kinases negatively correlates with Gas6 in established multiple sclerosis lesions. Am J Pathol 175:283-293. CrossRef Medline

Weinger JG, Brosnan CF, Loudig O, Goldberg MF, Macian F, Arnett HA, Prieto AL, Tsiperson V, Shafit-Zagardo B (2011) Loss of the receptor tyrosine kinase Axl leads to enhanced inflammation in the CNS and delayed removal of myelin debris during experimental autoimmune encephalomyelitis. J Neuroinflamm 8:49. CrossRef Medline

Yagami T, Ueda K, Asakura K, Sakaeda T, Nakazato H, Kuroda T, Hata S, Sakaguchi G, Itoh N, Nakano T, Kambayashi Y, Tsuzuki H (2002) Gas6 rescues cortical neurons from amyloid beta protein-induced apoptosis. Neuropharmacology 43:1289-1296. CrossRef Medline

Zagórska A, Traves PG, Lew ED, Dransfield I, Lemke G (2014) Diversification of TAM receptor tyrosine kinase function. Nat Immunol 15:920928. CrossRef Medline

Zhu C, Zhang A, Huang S, Ding G, Pan X, Chen R (2010) Interleukin-13 inhibits cytokines synthesis by blocking nuclear factor-kappaB and c-Jun $\mathrm{N}$-terminal kinase in human mesangial cells. J Biomed Res 24:308-316. CrossRef Medline

Zhu H, Sun X, Zhu L, Hu F, Shi L, Fan C, Li Z, Su Y (2014) Different expression patterns and clinical significance of $\mathrm{mAxl}$ and sAxl in systemic lupus erythematosus. Lupus. In press.

Zizzo G, Hilliard BA, Monestier M, Cohen PL (2012) Efficient clearance of early apoptotic cells by human macrophages requires M2c polarization and MerTK induction. J Immunol 189:3508-3520. CrossRef Medline 